\title{
DEPARTMENT of APPLIED SCIENCE
}

Safety Analysis Report on the Brookhaven Coal Flash Hydropyrolysis Experiment

- performed by

Process Technology Division

October 1976 BROOKHAVEN NATIONAL LABORATORY MASTER
UPTON, NEW YORK II973

INFORMAL REPORT 


\section{DISCLAIMER}

This report was prepared as an account of work sponsored by an agency of the United States Government. Neither the United States Government nor any agency Thereof, nor any of their employees, makes any warranty, express or implied, or assumes any legal liability or responsibility for the accuracy, completeness, or usefulness of any information, apparatus, product, or process disclosed, or represents that its use would not infringe privately owned rights. Reference herein to any specific commercial product, process, or service by trade name, trademark, manufacturer, or otherwise does not necessarily constitute or imply its endorsement, recommendation, or favoring by the United States Government or any agency thereof. The views and opinions of authors expressed herein do not necessarily state or reflect those of the United States Government or any agency thereof. 


\section{DISCLAIMER}

Portions of this document may be illegible in electronic image products. Images are produced from the best available original document. 
NOT I C E

This report was prepared as an account of work sponsored by the United States Government. Neither the United States nor the United States Energy Research and Development Administration, nor any of their employees, nor any of their contractors, subcontractors, or their employees, makes any warranty, express or implied, or assumes any legal liability or responsibility for the accuracy, completeness or usefulness of any information, apparatus, product or process disclosed, or represents that its use would not infringe privately owned rights. 


\title{
SAFETY ANALYSIS REPORT ON THE BROOKHAVEN COAL
}

FLASH HYDROPYROLYSIS EXPERIMENT

$$
\text { performed by the }
$$

Process Technology Division. Department of Applied Science Brookhaven National Laboratory

Upton, New York 11973

\author{
Staff \\ M. Steinberg, Head \\ P. Fallon, Project Eng. \\ R. Doering, Analytical Chem. \\ G. Farber, Technical Spec. \\ J. Smith, Technical Spec. \\ G. Woodson, Technician \\ Assisted by the Engineering Division, DAS \\ sponsored by \\ Fossil Energy Research Division \\ U. S. Energy Research and Development Administration \\ washington, D. C. 20545
}
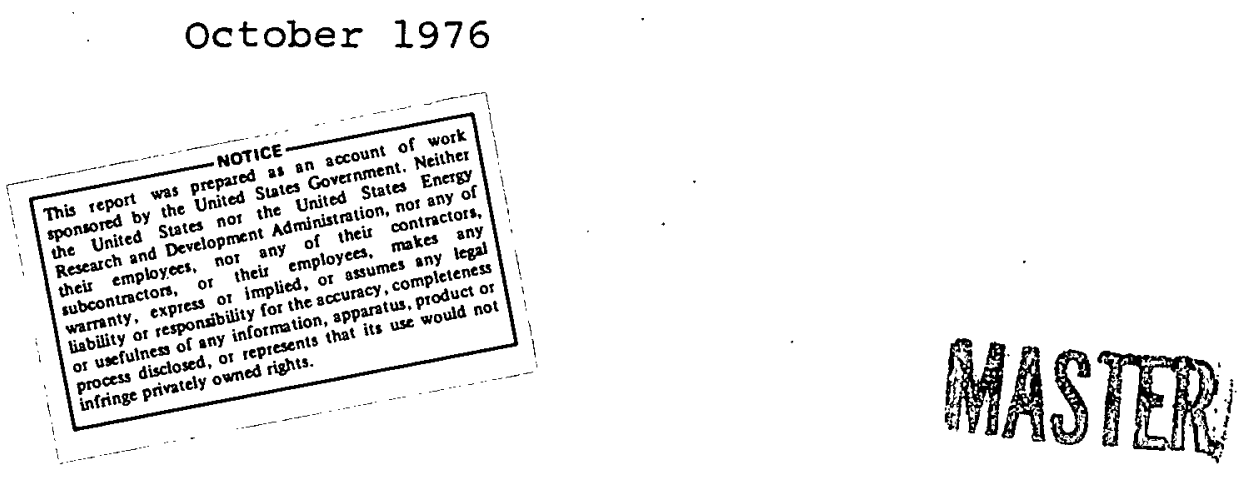


\section{Table of Contents}

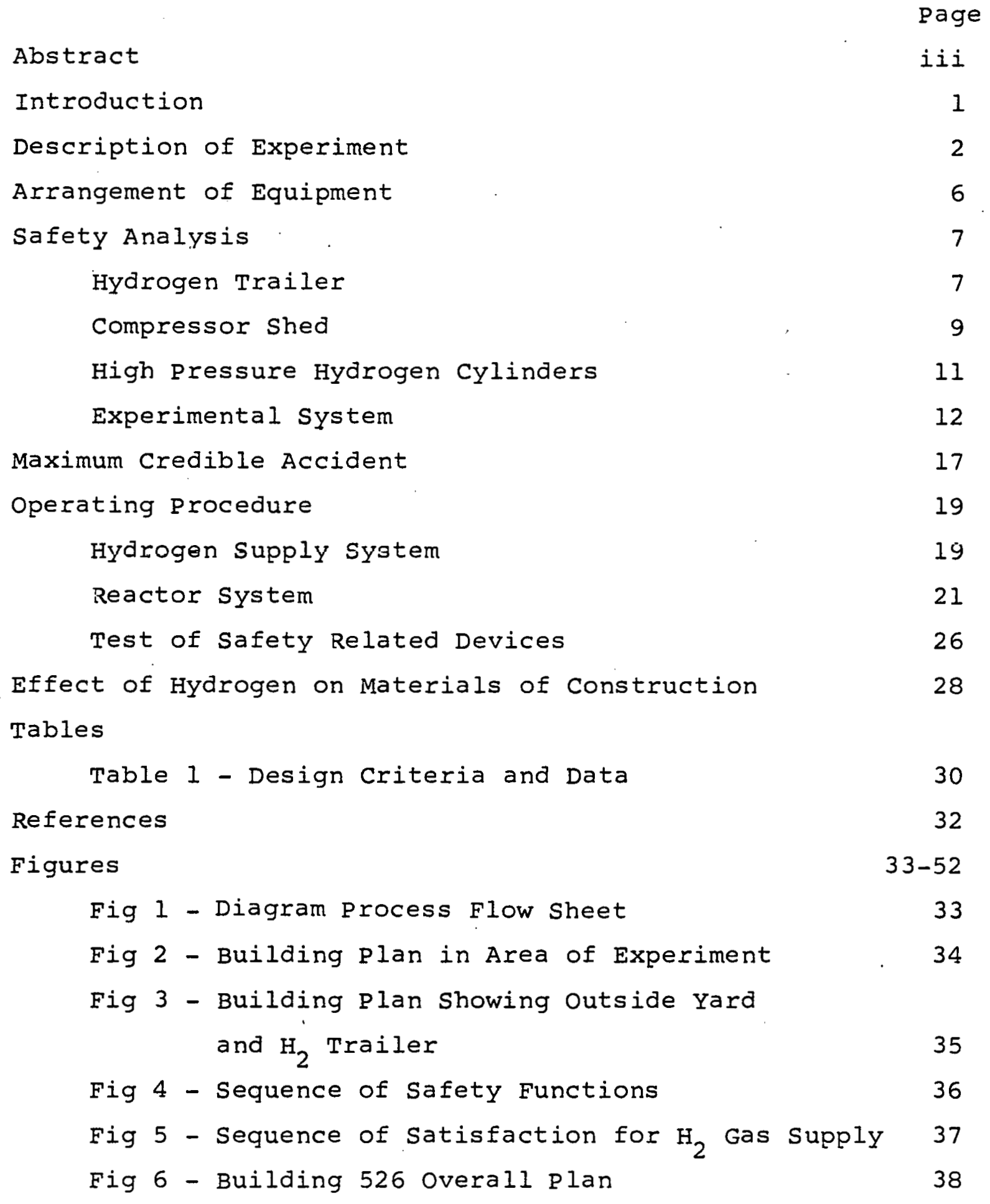


Fig. 7 - Welding Details-preheater to Reactor 39

Fig 8 - Welding Details-Sample Taps to Reactor 40

Fig 9 - Coal Hopper Flange Welding \& Electrical Terminal Details

Fig 10 - Char Trap Flange-Welding \& Electrical Terminal Details

Fig 11 - Operational Safety \& Alarm set Point Check sheet

Fig 12 - Engineering Drawing of Coal Feeder Vessel 44

Fig 13 - Copy of Coal Feeder Vessel's Hydrostate Test

Fig 14 - Engineering Drawing of Char Trap Vessel

Fig 15 - Copy of Char Trap Vessel's Hydrostate Test

Fig 16 - Engineering Drawing of 1 of 2 cold Trap Vessets

Fig 17 - Copy of water Cooled Exchanger's product Trap's Hydrotest

Fig 18 - Copy of $-70^{\circ} \mathrm{C}$ Cooled Exchanger's product Trap's Hydrotest

Fig 19 - Pressure vs. Torque for Metal \& "O" Ring Seals

Fig 20 - Rupture Life vs. Temperature ${ }^{\circ} \mathrm{C}$ for Preheater 


\title{
SAFETY ANALYSIS REPORT ON THE BROOKHAVEN COAL
}

FLASH HYDROPYROLYSIS EXPERIMENT

\author{
performed by the \\ Process Technology Division \\ Department of Applied science \\ Brookhaven National Laboratory \\ Upton, New York 11973
}

\begin{abstract}
The experimental apparatus for developing the process chemistry for the Flash Hydropyrolysis process in converting coal to liquid and gaseous hydrocarbon fuel and feedstock products is described. The construction and operation of the equipment is reviewed. A detailed safety analysis is made in preparation for initiating the experimental program.
\end{abstract}


SAFETY ANALYSIS REPORT ON THE BROOKHAVEN COAL

FLASH HYDROPYROLYSIS EXPERIMENT

$$
\text { performed by the }
$$

Process Technology Division

Department of Applied Science

Brookhaven National Laboratory

Upton, New York 11973

\section{Introduction}

The Flash Hydropyrolysis process (FHP) is a rapid, non-catalytic, gas-phase, coal hydrogenation process being developed for the purpose of producing liquid and gaseous hydrocarbons applicable to the production of distillate and gaseous fuels and feedstocks. 1,6

Pulverized coal is contacted with hot hydrogen at elevated pressure in a down-flow, entrained-bed, tubular reactor causing thermally induced openings in the polymeric heterocyclic hydrocarbon ring structure of the coal molecule. The free-radical ends add on hydrogen and through subsequent reactions form aromatic and alkyl hydrocarbons. On rapid cooling, the reaction is terminated stabilizing the products and minimizing dehydrogenation, repolymerization, carbonization and decomposition reactions. The mechanism of the process is recognized generally to proceed through three regions (1) rapid devolatilization of coal (milliseconds) (2) reaction at temperature and pressure for a period of time (seconds) and (3) rapid quenching (milliseconds to seconds) of the reaction products. The major thrust is to maximize liquid yields, however, substantial quantities of valuable gaseous hydrocarbons are also produced. All hydrocarbon products, including char containing unreacted carbon, are collected for analysis in order to obtain a complete material 
balance on the system. The purpose of the experiment is to obtain detailed process chemistry data, upon which a process design can be based with confidence and to assess the economic value of the process.

Initial experiments ${ }^{1}$ were conducted with a three-quarter inch diameter stainless steel reactor tube. Because of material and design limitations, this system could only be operated up to a maximum of $3 \mathrm{gm} / \mathrm{min}$ of $\mathrm{coal}$ and $4 \mathrm{gm} / \mathrm{min}$ of hydrogen at $700^{\circ} \mathrm{C}$ and 1500 psi for a period of only 20 minutes. The new experimental equipment shown in process flowsheet in Figure 1, extends the operating flow limits to $1 \mathrm{lb} / \mathrm{hr}$ of coal, $10 \mathrm{lb} / \mathrm{hr}$ of hydrogen, temperatures to $800^{\circ} \mathrm{C}$ and pressures to $4000 \mathrm{psi}$, with the capability of operating for up to at least two hours at maximum flow. Additional special features include special coal feeding, metering, and residence time devices and continuous on-line gas chromotographic analysis at a number of points along the reaction train of the apparatus. The experiment can also separate and produce significantly larger amounts of collectable liquid hydrocarbon products .

Description of Experiment

The experiment consists of the reactor system located in the high bay area of room 211, building 526 and the hydrogen supply system located external to this high bay area and the operating room adjoining the experimental bay area. The hydrogen system contains a 40,000 SCF compressed hydrogen trailer, a corblin double diaphragm compressor and ten 480 SCF, 6,000 psi capacity compressed gas cylinders attached to a common manifold. Most experimental runs will be conducted using the hydrogen from the high pressure cylinders, the compressor being used mainly to refill these cylinders from the gas trailer between runs. At 
high hydrogen flow rates, where the capacity of the cylinders is not sufficient to complete a long run, gas will also be taken directly from the compressor. Limiting the use of the compressor during a run is for the purpose of reducing the number of activities occurring simultaneously during a run.

Hydrogen at 6000 psi maximum enters the reactor system through a 7000 psi rated two stage pressure regulator located next to the experimental equipment. Here the pressure is reduced to that lesired for the particular run being conducted. The hydrogen then flows through a 5000 psi rotameter to a preheater before entering the reactor. The preheater is constructed of approximately 10 feet of 1/8" schedule 40 . Inconel 601 pipe formed into a 4 inch diameter coil welded to the reactor as detailed in Figure 7 and direct resistance heated electrically from a 23 KVA saturable transformer located outside the building. The heated hydrogen is then led into the main reaction tube consisting of a 1 inch inside diameter by $1 / 4$ inch wall Inconel 617 tube and is mixed down-flow with fine powdered coal particles of 150 microns or less. The total length of the reactor tube is 11 feet of which the first 8 feet is extremely heated. The coal is supplied at the top of the reaction tube from a syntron vibrating feed metering device as shown in Figure 21 mounted on a flange welded to the top of the reactor which is detailed in Figure 9 . The coal is fed to the syntron feed meter from a hopper attached to a load cell all of which is located inside a pressure contained at the top of the reactor tube. Hopper, load cell and syntron feeder provide a continuous weighing and metering record of the coal flowing to the tubular reactor during operation. The coal feed system can contain up to about 3 lbs of coal, enough to make a continuous run up to 3 hours at a flow rate of $\sim 1$ lb/hr. 
The coal and hydrogen then flows down the 8 foot heated reactor section of the tube to a 3 foot cooling section of the same tube. The reactor section is surrounded and heated by four 2 foot clam-shell type heaters of 2300 watts each and the cooling section contains eight $60 \mathrm{CFM}$ blowers to be used as necessary to cool the product laden gases to $300-400^{\circ} \mathrm{C}$ at which temperature the reaction is substantially quenched and prevents decomposition of the products. The reactor section contains sample taps placed at two foot intervals along its length for the purpose of determining the effect of residence time on product yield and distribution. These taps are fabricated from $3 / 8$ inch Inconel 617 rod 6 inches long drilled with a $1 / 8$ inch hole and welded to the reactor as shown in Figure 8 . Gas samples are removed at these taps and fed dierctly into the on-line gas chromatograph. The excess gas (approximately $100 \mathrm{ml} / \mathrm{min}$ ) is discharged to the atmosphere outside the experimental ared led by a line high above ground level. The reactior tube also features coal residence time devices located at the top entrance and the bottom exit of the reactor tube. These consist of electrical copper capacitor plates through which the coal flows and sends a signal to an oscilloscope located in the operating room the experiment.

From the reactor cooling section the gases enter a char trap kept at $350^{\circ} \mathrm{C}$ to stabilize the product and prevent liquid products from condensing. This is fabricated from a high pressure vessel similar to that containing the coal feeder, the cover of which is welded to the reactor as shown in Figure 10. Experience with the previous system has shown that the char will fall out of the gases simply by reducing the velocity to below the minimum fluidization velocity for the char particles and that filtration is unnecessary. Liquid products are removed from the gaseous effluent first in a 
water cooled condenser receiver attached to a smaller autoclave and then in a trichloroethane cooled condenser (operating temperature $\sim 70^{\circ} \mathrm{C}$ ) attached to an identical receiver. The first condenser is designed to remove all the oils $\left(>\mathrm{C}_{6}\right)$ formed by the reaction and most of the water. The second condenser is designed to remove the remaining water plus benzene, toluene, and xylene (BTX) formed by the reaction. The gas which now contains methane and heavier gaseous hydrocarbons $\left(<c_{6}\right)$ plus the large excess of hydrogen depending upon the original coal to hydrogen feed ratio is expanded through a pressure regulator and flow controller valve to atmospheric pressure. A positive displacement diaphragm gas meter is used to measure the intergrated total flow of effluent gas just prior to venting to the atmosphere through a 1/2" electrically grounded copper pipe extending to a height of 3 feet above the building height and 25 feet above ground level.

Helium gas is used to flush the system before and after each run. This is supplied from standard cylinders located in storage racks outside the building. A 2800 psi rupture disc and check valve are placed in this system to protect the cylinders from accidental over pressure from high pressure hydrogen.

All operations and instrumentation are remotely conducted in a closed room just outside the experimental high bay area. A material balance is made at the conclusion of each run by measuring the quantity of coal consumed, the char and the liquids produced and combining with the analysis of the coal, char, liquid and gaseous products plus the gas flow rate. A typical material balance for a lignite coal feed obtained at $60 \%$ conversion of the available carbon to hydrocarbon products is as follows: 
BXT

Light oils

Hydrocarbon Gases 35\%

oxides of Carbon. $6 \%$

Unreacted

$$
\frac{34 \%}{100 \%}
$$

The hydrocarbon gases are approximately $67 \% \mathrm{CH}_{4}$ and $33 \% \mathrm{C}_{2} \mathrm{H}_{6}$. A typical analysis of the light oils is as follows:

$\begin{array}{lc}\text { Hexane } & 7.2 \% \\ \text { Benzene } & 7.7 \\ \text { Naphalene } & 23.7 \\ \text { Phenanthrene } & 10.4 \\ \text { Anthracene } & 19.4 \\ \mathrm{C}_{2} \mathrm{O}^{+} & \frac{31.6}{100.0}\end{array}$

Arrangement of Equipment

A floor plan of the experimental area is shown in Figures 2 and 3. The hydrogen trailer is located 50 from the nearest occupied area as recommended by the compressed Gas Association and adopted by OSHA and is linked to the compressor shed via an overhead race-way approximately 18 feet above ground. The reactor system is supported in the center of a steel superstructure with working platforms at $6 \frac{1}{2}$ and 13 feet. Access to the platforms is via a safety ladder on the south wall of the room. The rotameter, diaphragm gas meter and pressure regulator are located to the north of the reactor with visual contact from the adjoining room from where the experiments are conducted and where the control console is located. The gas chromatograph is located on the opposite side of the reactor and is connected to the chromatograph console also located in the adjoining operating room. The high pressure cylinders, 
compressor, preheater power supply and chilled trichloroethane supply are all located outside of the experimental area.

\section{Safety Analysis}

The hazards associated with this experiment are the results of the severe operating conditions for which the reactor is

designed $\left(800^{\circ} \mathrm{C}+4000 \mathrm{psi}\right)$ and the quantity of hydrogen being used. Hydrogen in air is particularly hazardous because of its wide explosive and detonation limits of $4-74 \%$ and $20-65 \%$.

In analyzing the probability and consequences of an accident. in a facility of this nature, it is best to consider the area involved and the type of accidents that could occur. The areas (Figure 2+3-Plan of Coal Hydrogenation Experiment) involved are:

1) The hydrogen trailer

2) The compressor shed

3) The hydrogen cylinders

4) The experimental system

5) The experimental area (Room 211)

The types of accidents that could occur are:

1). A hydrogen leak

a) with ignition resulting in either a fire or explosion

b) without ignition

2) An equipment rupture

a) compressor

b) experimental equipment

Hydrogen Trailer

This is a standard 30 tube compressed gas trailer filled with $42,000 \mathrm{SCF}$ of hydrogen at a pressure of $2700 \mathrm{psi}$. The trailer is located inside the enclosed rear yard of building 
526, 50 feet from the nearest occupied area. There is no normal vehicle or pedestrian traffic anywhere in this yard. Approximately once a week two technicians spend an hour at a small shed 100 feet from the trailer and there are two more personnel occupying a laboratory approximately 75 feet from the trailer. The nearest normally occupied area is the flash hydropyrolysis experimental high bay area of room 211. occupancy of this area will normally be limited to four (4) people.

The 42,000 SCF of hydrogen contained in the trailer represents the equivalent of approximately 4,600 pounds of TNT if detonated with the stoichiometric quantity of air (29\% $\mathrm{H}_{2}$ in air) assuming $20.5 \mathrm{lb} \mathrm{TNT} / \mathrm{lbH}_{2}$. Although this indicates considerable potential energy, even if all the hydrogen were able to escape instantaneously the probability of a detonation is very low since the mixture would be uncontained. Since the cylinder tubes are opened manually and only one of the 30 tubes will be in use at any one time, a more realistic accident would be the uncontrolled escape of $1400 \mathrm{SCF}$ of hydrogen. If this were to ignite it could result in the eventful total consumption of the trailer. In this event, the only recourse would be to evacuate the area and notify the fire department. The trailer was reconditioned and recertified in october 1975. The recertification is valid for a period of five years. To safeguard against the uncontrolled release of hydrogen and minimize the hazards in the event of an accident the following measures have been taken.

1) The trailer is located out of doors and there are no unventilated enclosures or ignition sources.

2) A combustible gas detector head set to alarm at $1 \%$ 
hydrogen (25\% of the lower explosion limit-LEL) is located inside the trailer valves access doors. This will shut down all equipment associated with the experiment, close the fail safe pneumatically operated shut-off valve so-3 at the trailer and trip the fire alarm.

3) The access doors to the trailer are locked when the trailer is not in use.

4) The area is fenced in for limited access (See Fig 3).

5) Only one trailer tube is in use at anytime.

6) Hydrogen is taken from the trailer at the minimum compressor suction pressure of 500 psi.

7) Any malfunction detected in any other part of the experimental or hydrogen systems will close the pneumatically operated shut-off valve, so-3.

8) This valve is also closed by any one of four emergency buttons shown in Figure 2 .

9) Operating procedure calls for total of 6 valves between the hydrogen supply and compressor be closed when the compressor is not in use.

10) The trailer and compressor are tended by operating personnel when in use. This will be approximately three times a week for not more than three hours each time.

11) There is a check valve and 2800 psi rupture disc in the line between the compressor and trailer to prevent accidental over pressures for the compressor.

12) Each trailer tube is protected from over pressure by 3600-4000 psi rupture discs incorporated in the design of the trailer.

Compressor shed

This shed contains a 30,000 psi capacity corblin double 
diaphragm compressor recently reconditioned by Autoclave Engineers, Inc. for use in the coal hydropyrolysis experiment. Although the compressor output will be limited to 6000 psi for these experiments, the shed was designed for the full capacity of the compressor for possible future uses. In the event of a detonation in the shed, the over pressure created will be directed up and away from the experimental area by reinforced concrete walls at the sides and face of the comprcasor. The roof and jack wall are of light construction designed to give way under these conditions.

Even when the compressor is in operation, the inventory of hydrogen in the compressor system and shed is extremely small, estimated to be less than 0.1 pound and most of this contained in the compressor discharge surge bottle. If this were to mix with a stoichiometric quantity of air and detonate, shrapnel originating from the compressor components could develop and penetrate the back wall and/or roof of the shed. A hydrogen leak could result in either a detonation in the area around the compressor producing flying debris or a fire.

As with the hydrogen trailer, there is no normal vehicle or pedestrian traffic in this area except for the occasional usage of the previously mentioned small shed located 20-25 feet in front of the compressor shed (see Fig 3).

To minimize both the probability of an accident occurring and the danger to personnel in the event one should occur, the following measures have been taken:

1) The compressor shed is designed to localize the damage in the event of any accidents written.

2) Three 30,000 pound shielding block $5.5^{\prime} \times 3^{\prime} \times 8.5^{\prime}$ (shown in Fig 3) are placed in front of the compressor shed 
to stop debris from reaching the area of the small shed in the event of an accident.

3) The shed contains combustible gas detector set to alarm at $1 \%$ hydrogen (25\% LEL) and a fire detector both of which alerts the fire department and shuts all systems down, shutting all hydrogen supply valves, interrupting all power to the experimental equipment and compressor, venting the hydrogen in the reactor to the atmosphere through $1 \frac{1}{2} "$ grounded copper pipe, three feet above the building and 25 feet above ground.

4) There are no ignition sources in the shed.

5) The compressor output is limited to 6000 psi by internal mechanical pressure limiter and an electrical pressure switch.

6) If the pressure should exceed 6000 psi, a 6300 psi relief valve is provided to vent the excess pressure to the atmosphere through $1 \frac{1}{2}$ " grounded copper pipe 3 feet above ground.

7) In case of failure of both the pressure switch and relief valve, a 6700 psi rupture disc located outside the shed, vents all hydrogen to the atmosphere through the same path as above.

8) The compressor has been tested to insure it will not under the most adverse conditions (the inlet valve closed and negative suction pressure) allow air to enter the system.

High Pressure Hydrogen Cylinders

There are ten, 6000 psi cylinders containing $480 \mathrm{SCF}$ of hydrogen each which supply hydrogen to the experimental equipment. Although this represents 25 lbs of hydrogen, there are few hazards associated with these cylinders since 
they are located out of doors under a sun shade and there are no moving parts or ignition sources.

Mechanical damage could occur that would result in the rupture of one or more of the cylinders or cause a break in the hydrogen feed line while the cylinders are in use. Again, since the hydrogen would be uncontained; the likelihood of a detonation is very small. The most probable result would be escape of the gas either with or without a fire. To reduce potentiality of an accident occurring, the following measures have been taken:

1) The cylinders are located in a remote area along side the compressor shed (Fig 2) and inside the fenced enclosure.

2) There is adequate ventilation.

3) The cylinders are securely fastened to the compressor shed.

4) The cylinders are protected from over pressure by the same safeties used for the compressor (6300 psi pressure relief valve and 6700 psi rupture disc).

5) The cylinders are DOT rated and have been hydrostatically tested within the required period of time. (The next test is due March 1982).

6) Operating procedure requires all cylinders be closed from the system at the cylinder valves when not in use.

7) Operating procedure also requires the compressor, hydrogen trailer and.cylinders be tended during refilling.

Experimental system

This system is considered to consist of all equipment inside the experimental area as shown in Fig 1.

The problems and sources of hazards associated with

this area are:

1) A maximum of 0.9 pounds of hydrogen at 4000 psi can be contained in the system. 
2) Equipment is in a confined area.

3) There are operating personnel in close proximity (up to four operators, approximately 30 feet from the experiment).

4) There are a number of ignition sources.

5) The system is at high temperature and pressure (up to $800^{\circ} \mathrm{C}$ $\& 4000$ psi) .

An accident could result in a fire with damage to the experimental equipment or a detonation either within or outside the experimental equipment. To reduce the probability that the total inventory of hydrogen will be released to the experimental area or that hydrogen will enter this area from the hydrogen supply in the event of a leak, the following precautions have been taken:

1) A pressure switch is incorporated in the system which as part of the operating procedure is set at 200 psi below the operating pressure, this will sense a reduction in pressure in the event of a rupture or leak and shut down all systems, shutting all hydrogen supply valves, interrupting power to the experimental equipment and compressor and venting hydrogen in the reactor to the atmosphere through $1 \frac{1}{2} "$ grounded copper pipe, three feet above the building and 25 feet above ground.

2) Two explosive gas detector heads are located above the upper autoclave flange (coal feeder) and two heads are located above the lower autoclave flange (char trap). Each are set to detect $1 \%$ hydrogen ( $25 \%$ LEL) and to sound the fire alarm and shut down all systems as above.

3) If a leak should result in a fire, a $180^{\circ} \mathrm{F}$ fixed temperature fire sensor which is interlocked with the experiment will sound and shut down all systems, as above. 
4) Two independently controlled pneumatically operated shutoff valves are located at the high pressure cylinders to isolate the hydrogen supply from the experimental area. Each is interlocked to close with any malfunction in the equipment. To reduce the problem of containing hydrogen in a confined area, the following measures have been taken:

1). A $4000 \mathrm{CFM}$ exhaust fan is located directly above the equipment and interlocked such that no electrical equipment can operate or hydrogen flow to the experiment unless the fan is in operation.

2) The experiment is enclosed in a "herculite" (fiber-glass reinforced non-flammable plastic sheet) tent approximately 6'x14'x25' (2100 $\mathrm{ft}^{2}$ ) directs all air to the fan over the equipment through a 9 square foot opening for viewing the flow meters and pressure gauges.

3.) The room in which the hercultie enclosure is located is $22^{\prime} \times 32^{\prime} \times 25^{\prime}\left(17,600^{\circ} \mathrm{ft}^{3}\right)$ and contains fire and explosive gas detectors and an exhaust fan.

Although it is necessary that operating personnel be in visual contact with the experiment during operation, the following precautions have been taken to prevent injury in the event of an accident.

1) All experimental equipment is located behind $1 / 2$ " wire rope blasting mats which will stop all anticipated projectiles $90^{\circ}$ incident to the mat and $1 / 4$ " or larger projectiles $45^{\circ}$ incident to the mat.

2) Operation is conducted from the adjacent room behind a fire door with visual contact through a safety wire reinforced glass and the use of closed circuit TV monitors. 3) By enclosing the experiment in the herculite tent 
previously mentioned, the probability of a detonation or less outside the tent is reduced. If a detonation were to occur, it would most likely occur inside the tent, leaving the room as an area in which the overpressure can vent. This would greatly reduce the impact to the area of the fire door (Fig. 2).

Ignition sources cannot be completely eliminated, only reduced. All electrical components requiring power while the system is being brought up to operating pressure are non-sparking, only those which are activated after personnel are behind the closed fire door are ignition sources as follows:

Electrical Components Inside Hydrogen Tent Non-Sparking

Low pressure switch

High pressure switch

Exhaust fan

Explosive gas detector

Ignition sources

Preheater

Reactor furnaces

Coal feeder

Flow control meter

Cooling fans

In order to guard against rupture of the equipment due to exceeding the maximum design pressure and/or temperature of $4,000 \mathrm{psi}$ and $800^{\circ} \mathrm{C}$ the following safety devices have been incorporated:

1) A high pressure pressure switch to shut the system down 
at 4,200 psi, shutting all hydrogen supply valves, interrupting power to the experimental equipment and compressor and venting the hydrogen in the reactor to the atmosphere through $1 \frac{1}{2} "$ grounded copper pipe, three feet above the building and 25 feet above ground:

2) A pressure relief valve set at 4,500 psi which vents outdoors through the grounded copper pipe mentioned above.

3) A 4,880 psi rupture disc which vents through the same path as the pressure relief valve.

4) Four temperature controllers set at $825^{\circ} \mathrm{C}$, one for each reactor furnace which shuts the system down as above if this temperature is exceeded.

5) Two pyrovanes set at $775^{\circ} \mathrm{C}$ and attached to the preheater which also shuts the system down as above if this temperature is exceeded.

6) A mercury switch located on the temperature recorder and set at $825^{\circ} \mathrm{C}$ which shuts the system down as above if any temperature exceeds this value.

The controls for the experimental equipment are all designed for fail safe operation, meaning if a component should fail or a switch break either the equipment is inoperative or if in use would shut down. Also any open circuit in the wiring such as caused by fire would have the same effect. (See figures 4 and 5 for a summary of the interlocks). 
Maximum Credible Accident

This accident would be the detonation of a stoichiometric mixture of hydrogen and air. (29\% hydrogen) throughout the $17,600 \mathrm{ft}^{3}$ high bay experimental area. This represents 26 lbs of hydrogen or the equivalent of 536 lbs of TNT (Fig. 3). Even if only that hydrogen contained in the high pressure cylinders were allowed to form an explosive mixture and detonate, the damage would be very severe. If this should occur, the high bay experimental area would probably be totally destroyed, the roof may not fall due to the independent structure for the overhead crane but this would be of little concern. Operating personnel in the adjacent room behind the fire door would probably sustain serious injuries with possible fatalities.

Because the experimental area was originally used in the study of critical assemblies, the external walls were lined with 4 feet of solid cement block for a height of 8 feet for radiation shielding. Most of this shielding is still in place as shown in Fig. 6. In the event of a major detonation in this area, this added mass would offer considerable protection to the rest of the building. The most vulnerable area appears to be the hall to the east of room 114 which has very light traffic.

The occupancy of building 526 is presently approximately 30 people, 20 of which occupy offices in rooms 101 to 110 and 200 to 204 (Fig. 6). The highest concentration of personnel during operation of the experiment would be in the control console area of room 211. This will normally be limited to two technicians, and analytical chemist, and 
a supervisor. During operation, the area will have limited access, controlled by the fence previously described (Fig 3) and signs reading "Hydrogen Experiment in Progress, Do Not pass" posted at all entrances to the area. The steps taken to avoid an accident of this nature are those taken to avoid accidents in the experimental area and consist of the following:

1) Limited use of hydrogen.

2) Automatic shut off of hydrogen in the event of a mishap.

3) Adequate ventilation (approximately one air change every 4 minutes).

4) The use of combustible gas detectors. 


\section{Operating procedure}

Hydrogen Supply System

When the hydrogen supply in the ten 6000 psi cylinders needs replenishment, hydrogen from the trailer must be compressed into these cylinders as follows: (Refer to Fig 1 ).

1) Valves $V-1, V-13$, and $V-14$, the compressor inlet line, discharge line and discharge vent valves located on the compressor control panel in the experimental area are closed.

2) Valve V-11 located next to the 6000 psi cylinders is closed.

3) Valve V-12 located next to valve $V-11$ is opened.

4) One of the 30 tubes in the trailer is opened to the trailer manifold and to valve $\mathrm{V}-2$. This should be a tube marked "in use". If none are so marked the next full tube may be used and the "full" tag removed.

5) Valve $V-2$ on the trailer is opened and PCV-4 set to 500 psi, the minimum compressor suction pressure.

6) The valve on pressure regulator PCV-4 is opened, the experimental area ventilating fan is turned on and the pneumatically operated shut-off valve SO-3 is actuated from the control console. The fan switch is located to the right of the compressor panel in the experimental area. No electric or pneumatic controls can be actuated 
without this fan in operation.

8) The compressor is started from the control console.

9) When the compressor préssure has reached 6000 psi, valve V-13, the discharge line valve is opened. The pressure should now drop to that of the 6000 psi cylinders.

10) When the compressor pressure again reaches 6000 psi, the cylinders are full. While the cylinders are filling, the compressor suction pressure is monitored. If it drops below 500 psi the trailer tube in use should be closed off, the tube marked "empty", a full tube opened to the trailer manifold and the new tube marked "in use".

When the 6000 psi cylinders are full, the compressor is shut down as follows:

1) Valve $V-1$, the inlet line valve, is closed.

2) The compressor is stopped and valve V-13 the discharge line valve is closed.

3) Valve V-14, the discharge vent valve, is opened momentarily to reduce the pressure in the compressor to atmospheric and then closed.

4) Valves $V-15$ and $V-16$, the pressure valves are closed.

5) Valve $V-2$ on the trailer and valves $V-12$ and $V-3$ at the 6000 psi cylinders are closed.

6) The valve for the trailer tube in use, valve $\mathrm{V}-12$ and the 
valve connecting it to the trailer tube and the valve on the pressure regulator are all closed.

7) The pneumatically operated shut-off valve so-3 is deactivated.

8) The trailer doors are closed and locked.

\section{Reactor system}

Assuming the autoclaves have been disassembled from the reactor system after the completion of an experiment, reassembly and start-up procedures are as follows:

1) The product and char trap autoclaves are cleaned and the metal seals inspected for flaws.

2) The coal feeder is refilled with a weighted quantity of coal; the autoclaves are assembled to the system and the bolts torqued to the specifications given by the manufacturer as shown in Figure 19.

3) The hinged blast mat is put in place to close off the experimental equipment.

4) The herculite hydrogen tent around the experimental equipment is put in place (The tent must direct all the air passing through the ventilating fan over the reactor system).

5) The power is turned on to the control panel by actuating the switch located on right hand side of the panel. 
(Caution: the breaker box from which the panel receives power must remain on at all times as the combustible gas detectors receive power directly from this breaker).

6) The fan is turned on at the switch provided to the right of the compressor panel (as previously mentioned all controls are interlocked with this fan).

7) The "low system pressure" bypass button is depreseed (this bypass will clear when the system has reached operating pressure).

8) The control console is inspected to insure the following:

a) The four reactor furnace high temperature safeties are set at $825^{\circ} \mathrm{C}\left(1517^{\circ} \mathrm{F}\right)$ and the variable transformers for this furnace are turned down.

b) The two preheater high temperature safeties are set at $775^{\circ} \mathrm{C}\left(1427^{\circ} \mathrm{F}\right)$.

c) The three pneumatically operated valves are closed.

d) The emergency vent is closed.

e) The preheater, reactor heaters, coal feeder and compressor are off.

f) The temperature recorder is on.

g) The preheater controller is off.

h) There is power to the explosive gas detector and the 
"trouble" and "high gas" lights are out.

i) All white enunciator lights are out and working (press the black enunciator lamp test button).

j) The green system clear light is on.

9) Valves $\mathrm{V}-5, \mathrm{~V}-7$ and $\mathrm{V}-9$ are closed and valve $\mathrm{V}-8$ is opened.

10) lihe vacuum pump is started.

11) When the vacuum system has reached $5 \times 10^{-1}$ TORR, valves $V-6$ and $V-7$ are opened and the system also pumped down.

12) The system is checked for leaks using freon and leak detector incorporated in the vacuum system.

13) The system is considered leak tight when no leaks are detected by the leak detector and it can maintain a vacuum of $5 \times 10^{-1}$ TORR.

14) The system is pressurized with helium to 250 psi by opening valve $\mathrm{V}-5$. This should be done slowly as not to disturb the fine coal particles in the coal feeder. The system is left at this pressure for approximately 20 minutes to again check for leaks.

15) Valve $\mathrm{V}-9$ is opened (it is assumed PCV-2 and PRFC-1 are both set from the previous experiment).

16) The system is flushed with 5 system volumes of helium (approximately 3 feet feet $^{3}$ ). 
17) Valves $V-5, V-7$ and $V-9$ are closed.

18) Pressure controller PCV-I is backed off completely.

19) The adjustable low system pressure switch located on the upper level behind the preheater is set to a pressure 200 psi below the intended operating pressure.

20) The flow controller PRFC-1 is closed from the control console.

21) The water is turned on to the water cooled copper heat sinks at the preheater, the heat sink at the top of the reactor and the water cooled condensor.

23) Valves $V-9$ and $V-10$ are opened slowly and all personnel removed from the experimental area to the contrul room and the fire door closed.

24. Once the helium pressure in the system has been reduced below 50 psi, the pneumatically operated valves so-1 and so-2 are opened and the system is brought up to operating pressure with hydrogen by slow adjustment of PCV-1 from the control console while an operator depresses the low system pressure by-pass button (if gas enters the system rapidly, the fine coal particles in the feeder will be blown from the hopper).

25) The reactor furnaces are brought up to temperature using the four variable transformers.

26) The hydrogen flow rate is set using the flow controller 
PRFC-1 and the positive displacement gas meter (once the flow rate is set, the rotameter flow meter reading is recorded and this meter used to detect and adjust drifts in flow rate). The reactor temperature may drop slightly due to the introduction of cold hydrogen but should not be adjusted at this time.

27) The preheater is turned on and brought up to temperature.

28) The reactor temperatures are adjusted if necessary.

29) The coal feeder load cell is turned on, the time recorded and the coal feeder started.

30) The cooling fans are turned on as necessary to maintain the gas temperature in the char trap below $200^{\circ} \mathrm{C}$. The top fan is always turned on first and the rest in decending order.

31) At the conclusion of the run, the coal feeder, hydrogen supply, reactor furnaces, preheater and temperature recorder are turned off. (The cooling fans remain on to avoid overheating the char trap).

32) The reactor pressure is allowed to bleed down to atmospheric through the flow controller.

33) When the system has reached atmospheric pressure, $v-10$ is closed and $V-7$ and $V-5$ are opened to flush the system with helium ( $V-4$ the helium supply valve is normally left open). 
34) While the system is being flushed, V-3 and V-11 located at the high pressure cylinders are closed.

35) After a minimum of 5 reactor system volumes (approximately 3 feet $^{3}$ ) have passed, $V-5, V-7$, and $V-9$ are closed and the autoclaves opened to remove the products and make a material balance.

\section{Test of Safety Related Devices.}

Most of the electrical components must be functional before the equipment can be made operational therefore these components need not be tested on a routine basis. Those components which are required for safe operation and which will need testing are:

1) The exhaust fan interlock.

2) The six pyrovanic used as high temperature cutouts.

3) The high temperature cutout feature of both the temperature recorder and the preheater controller.

4) The high and low pressure reactor pressure switches.

5) The four emergency buttons.

6) The combustible gas detector system.

7) Compressor high pressure shut off.

The plant engineering group at BNL will test the gas detector system every three months in conjunction with the fire alarm system. These gas detectors plus the other components mentioned above will be tested weekly by the operators and the fact noted on a check sheet located on the 
control console (see appendix). The test procedures to be used are as follows:

1) The fan interlock will be tested by attempting to actuate each of the pneumatically operated valves with the fan off and by closing the emergency dump valve with the fan on and turning the fan off to see if this valve opens.

2) Testing of the pyrovane high temperature cutouts will be accomplished by moving the set point to cause an alarm condition.

3) The temperature recorder and preheater controller will be tested by manually raising the temperature indicator to the set point.

4) To test the high pressure reactor pressure switch, hydrogen will be let into the system while at room temperature until the emergency dump valve opens (approximately 4200 psi). In order to avoid total loss of the hydrogen, the dump valve will be immediately reclosed. The pressure in the system is now allowed to bleed out through the flow controller to insure the dump valve reopens when the pressure in the system drops below that for which the low pressure switch is set.

5) The emergency buttons are tested by opening one of the hydrogen supply valves, closing the dump valve and pressing the button to insure the supply. valve closes and the dump valve opens. This is repeated for each valve.

6) To test the gas detector system, it must first be 
disconnected from the fire alarm at the fire control station. A mixture of $1 \%$ hydrogen and air is then directed into the detector head while observing the meter needle deflection on the face of the instrument. (Zero setting of this meter should be between the 0 and 2 mark on the right side). If this does not cause the system to alarm, the setting should be changed accordingly.

7) The compressor high pressure shut off is tested when the high pressure cylinders are refilled. This is done by allowing the compressor to shut off automatically at 6000 psi while observing that this pressure is not exceeded.

Effect of Hydrogen on the Materials of Construction

Except for the reactor, preheater, high pressure manifold, pressure regulators and compressor feed line from the hydrogen trailer, all metallic materials in contact with hydrogen at elevated pressure is of 316 stainless steel which is generally recognized ${ }^{2,3}$ as not being adversely affected by hydrogen. The high pressure manifold and pressure regulators are of brass and the hydrogen feed line from the trailer is 347 stainless steel, a slightly less desirable alloy than 316 stainless steel. The 347 stainless steel was chosen for this application for economic reasons and since it is at $500 \mathrm{psi}$, which is only a fraction of its normal allowable working pressure.

The preheater is of 601 Inconel and the reactor 617 Inconel. The International Nickel Co., Inc. manufacturer of these alloys has tested samples of their alloys ${ }^{4}$ cathodically 
charged with 30-40 ppm of hydrogen and found them not to suffer any reduction in ultimate yield strength. They did observe as much as a $40 \%$ reduction in ductility at the yield point but claim this to be less of a reduction than samples of 300 series stainless steel tested under the same conditions. NASA has tested Inconel alloys ${ }^{5}$ and confirmed Huntington Alloys' finding that the reduction in ductility decreases at elevated temperatures. 


\section{Table 1}

Brookhaven coal Flash Hydropyrolys is Experiment

\section{Design and Construction Data}

Maximum Design Operating Conditions

Coal Flow Rate

Hydrogen Flow Rate

Preheater Temperature

Reactor Temperature

System Pressure

Duration of Runs

Reactor System

Experimental Lines

Preheater (Fig 20)

Reactor
$11 \mathrm{~b} / \mathrm{hr}$

$101 \mathrm{~b} / \mathrm{hr}$

$750^{\circ} \mathrm{C}$

$800^{\circ} \mathrm{C}$

4000 psi

2 hrs
$3 / 8 " \times 0.049 " 316$ s.s.

$1 / 4 " \times 0.035 " 304$ S.S.

1/8" Inconel 601 Pipe

3400 hr Rupture Iife
$4000 \mathrm{psi}+750^{\circ} \mathrm{C}$

$11 / 2 " \times 0.25 "$ Inconel

617 Tubing

$<10,000$ hr Rupture Life @ $4000 \mathrm{psi}+800^{\circ} \mathrm{C}$

Coal Feeder Vessel - 2 Gal 5,500 psi Pressure Vessel - Fig 12

Char Trap - I Gal 5,500 psi Pressure Vessel - Fig 14

Product Traps - I L. 5,800 psi Pressure Vessels - Fig 16

Pressure Relief Valve $\quad 4,500 \mathrm{psi}^{* *}$

Rupture Disc $\quad 4,880 \mathrm{psi} \pm 2 \%$

Gas Meter

$1,000 \mathrm{SCF} @ 1 / 2 " \mathrm{H}_{2} \mathrm{O}$

Max. Press. of $100^{2} \mathrm{psi}$ 
Hydrogen Trailer

$\begin{array}{ll}\text { Capacity } & 42,000 \mathrm{SCF} \\ \text { Pressure } & 2,700 \mathrm{psi} \\ \text { Certified } & 10 / 75 \text { Valid for } 5 \text { years } \\ \text { Rupture Disc } & 2,800 \mathrm{psi} \pm 2 \% \\ \text { Discharge Pressure } & 500 \mathrm{psi} \\ \text { Discharge Line } & 1 / 4 " \times 0.035^{\prime \prime} 347 \mathrm{S.S} .\end{array}$

Compressor

Max. Pressure

30,000 psi

Operating Pressure

$6,000 \mathrm{psi}$

Suction Pressure

500 psi

Rupture Disc

Pressure Relief Valve**

$6,700 \mathrm{psi} \pm 2 \%$

Discharge Line

$6,300 \mathrm{psi}$

1/4" Super Pressure 316 \$.S. Tubing

Supply Cylinders ${ }^{* * *}$

Operating Pressure

$6,000 \mathrm{psi}$

Quantity

10

Total Capacity

4,800 SCF

Total weight of $\mathrm{H}_{2}$

25 lbs

**Full open at $110 \%$ pressure

Reseats at $90 \%$ pressure

***Cylinders share rupture disc, relief valve and lines with compressor. 


\section{References}

1. M. Steinberg and P. Fallon, "Coal Liquefaction by Rapid Gas Phase Hydrogenation", BNL Report 19507, (October 1974) presented at 169th National American Chemical Society Meeting, Philadelphia, Pa., April 6-11, 1975. Published in Hydrocracking and Hydrotreating, edited by J. W. Ward and S. A. Qader, Amer. Chem. Society, Washington, D. C., 1975, pp. 123 .

2. J. M. Holmes, H. D. Cochran, Jr., M. S. Edwards, D. S. Joy, and P. M. Iantz, "Hydrocarbonization Re'search Phase I Report: Review and Evaluation of Hydrocarbonization Data", Oak Ridge National Iaboratory Report ORNL-TM-4835, August 1975.

3. C. J. M. Northrup, Jr., R. P. Wemple, and L. P. Baudoin, "Considerations when Designing, Assembling, and Operating a Gaseous Hydrogen Pressure System", Sandia Laboratories Report 805.40.25.90-GO-0I (E2217), November 1972 .

4. Private communication on $3 / 9 / 76$ and $4 / 19 / 76$ with charles Sponaugle of Huntington Alloys, Huntington, West Virginia.

5. Private communication on $4 / 22 / 76$ with Bryan MC Pherson NASA, Huntsville, Alabama.

6. M. Steinberg, T. V. Sheehan and $Q$. Lee, "Flash Hydropyrolysis process for Conversion of Lignite to Liquid and Gaseous Products", presented at 170th National American Chemical Society Meeting, New York, New York, (BNL 20915), April 1976 . 

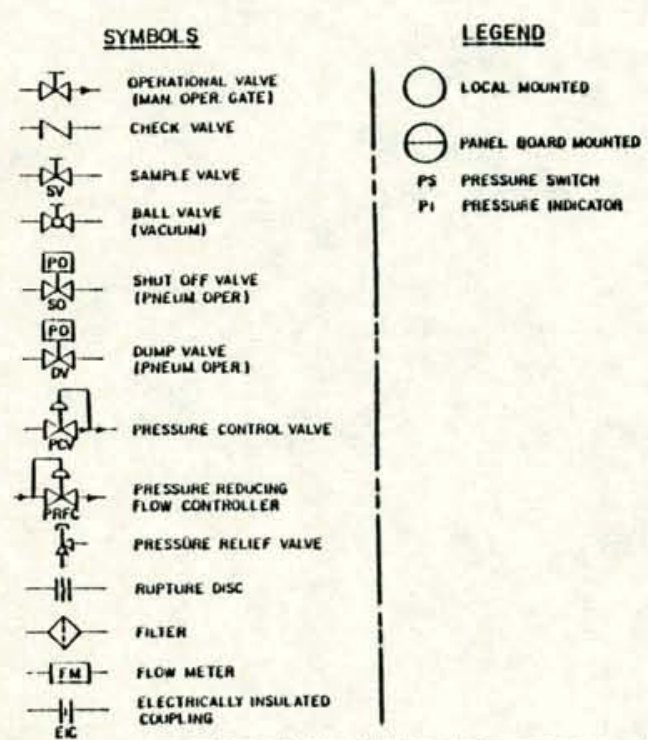

PRESSURE RELIEF VALVE

I RUPTURE DISC SEITING

Pav-1 Yoopsis

$\prod_{d \mathrm{D}} \int_{\substack{1,000 \mathrm{COM} \\ \text { EXNAUSI FN }}}$

Ba-1

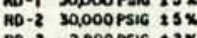

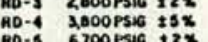

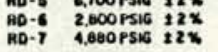

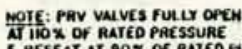

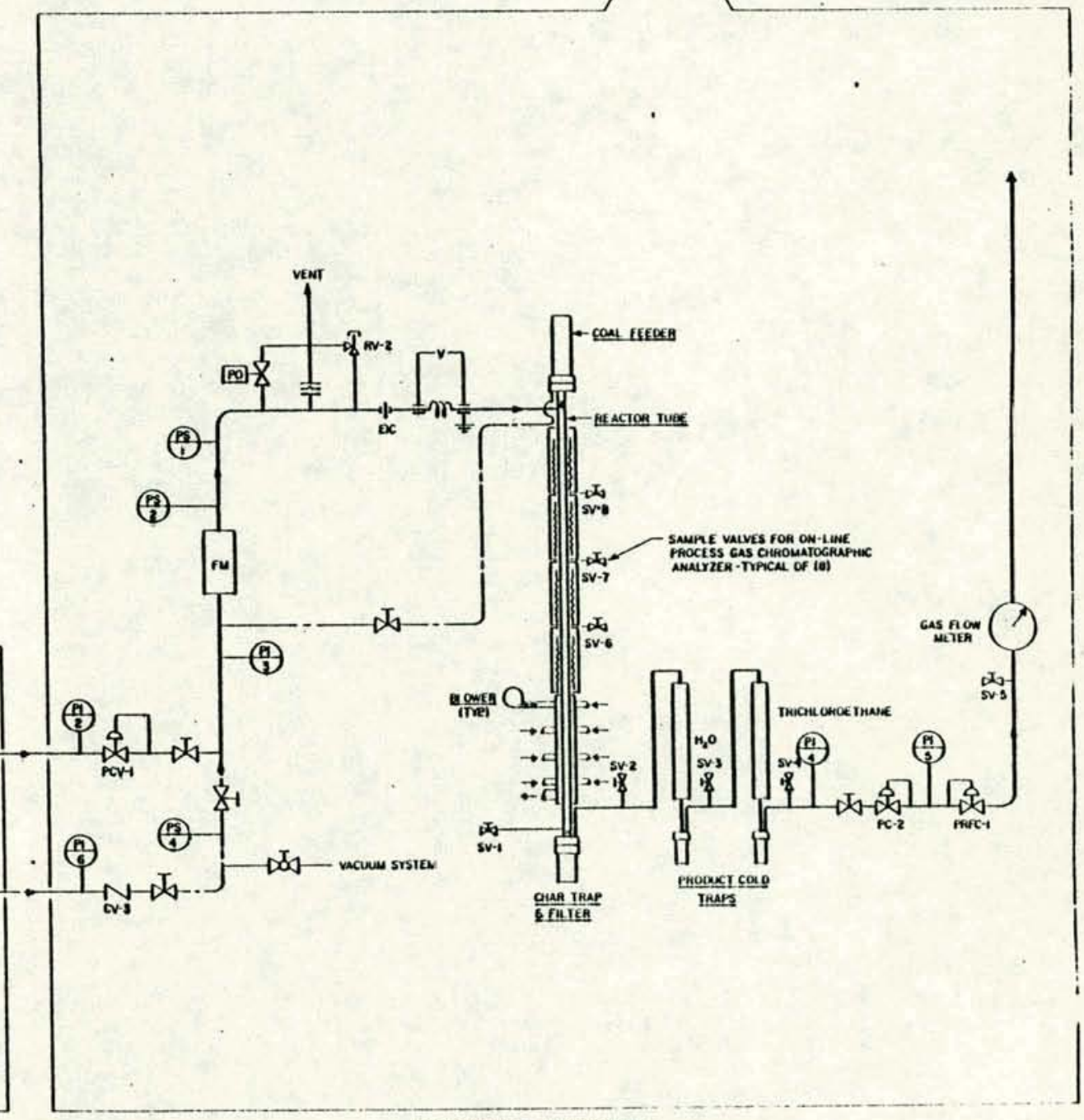

COMPRESSOR SHED

IRAIIER

GAS SUPPLY SHED

EXPERIMENTAL EIICLOSURE

Pig 1 
BRDOKHAVEN NATIONAL LABIRATIRY

BY.

DATE.

CHKD. BY
sUBJECT... Plan of Coal

FHP Experiment

DEPT. OR PROJECT.
SHEET NO.

DF

JםB NO

Scale $3 / 16^{\prime \prime}=1$

\ EMERGENCY STOP BUTTONS

OPERATING ROOM AND INST RUMENTATION
$C O A L F R E P A R A T I O N$

I A B O R A T O R Y

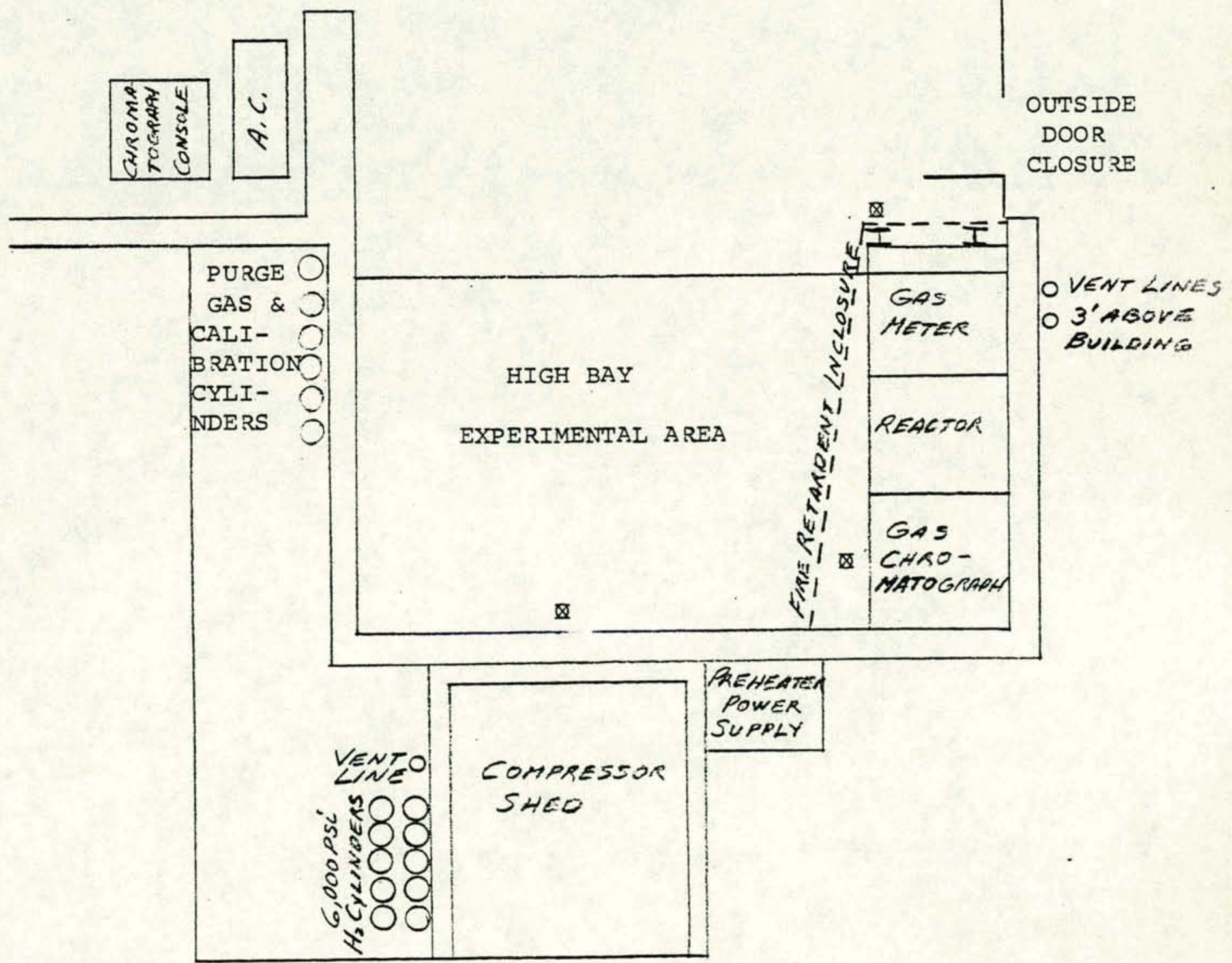

Fig. 2 
BRDOKHAVEN NATIONAL LABORATORY

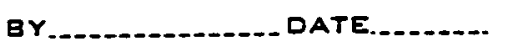

CHKD. BY

DATE.......

-

SHED

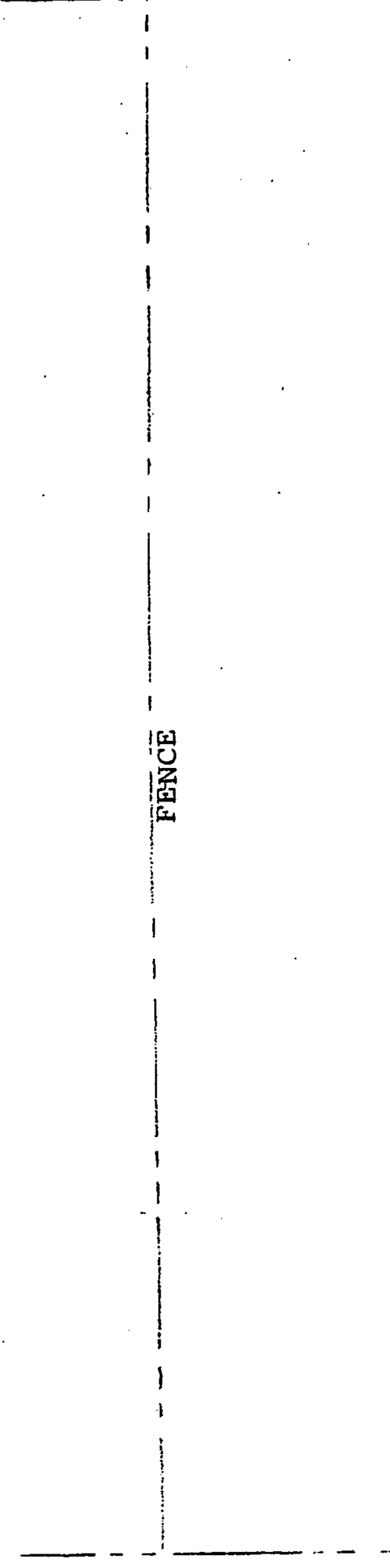

lan _of coal FHP_Area

DEPT. OR PROJECT.

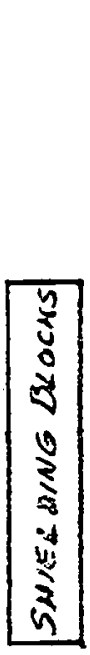

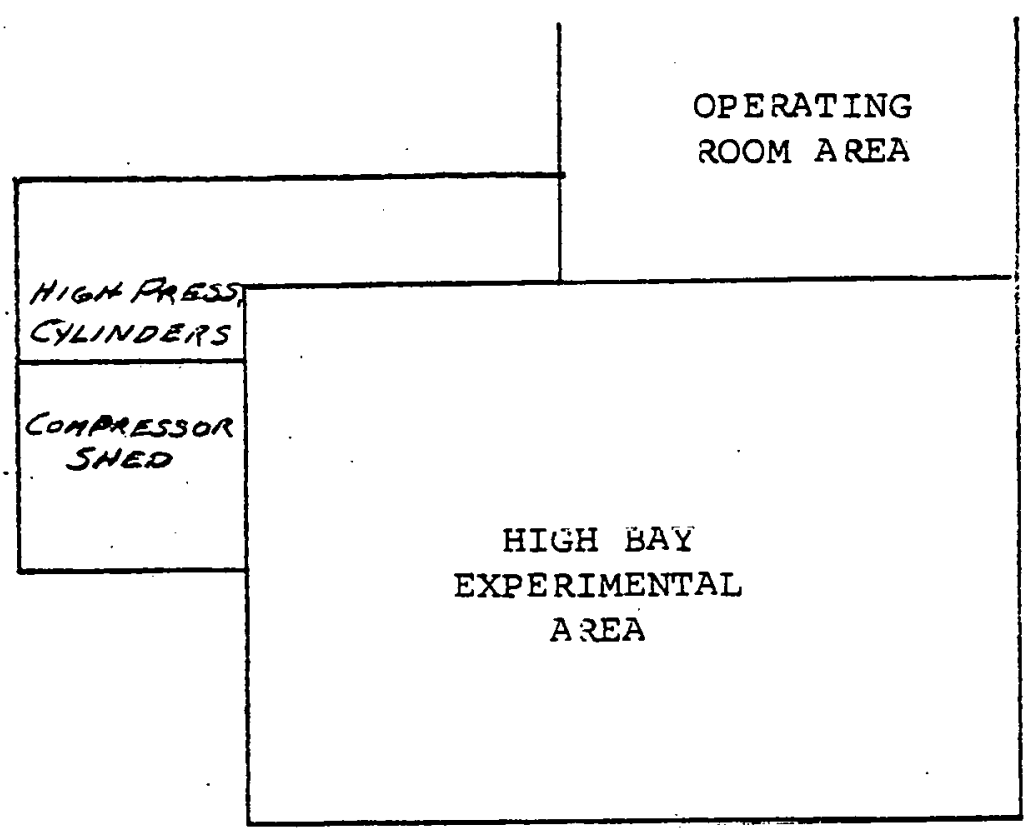

SHEET NO.

JaG NO. Scale $3 / 32 "=1$

OPERATING ROOM AREA

\title{
EPERIMENTAL \\ $A: R E A$
}

\author{
O U T S I. D E $\quad$ Y A R \\ B U I I D I N G 526
}


GROOKHAVEN NATIONAL LAEDFATORY

Br

DATE.

SUBJECT SEQUENCE OF_ SATISFACTION FOR

CHKD. BY DATE. $\mathrm{H}_{2}$ GAS_ SUPPLY

JaB NO.

DEPT. OR PROJECT.

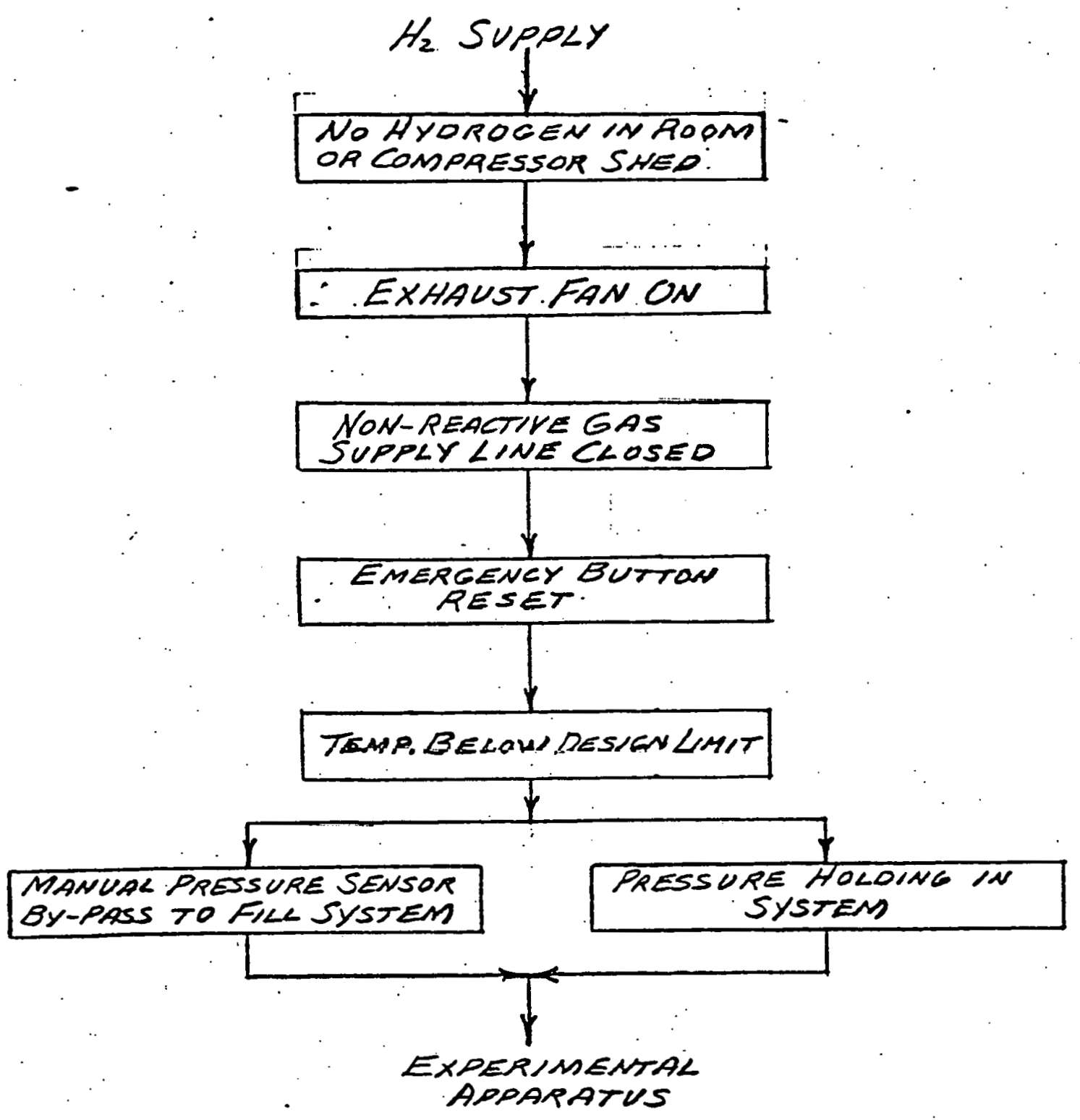




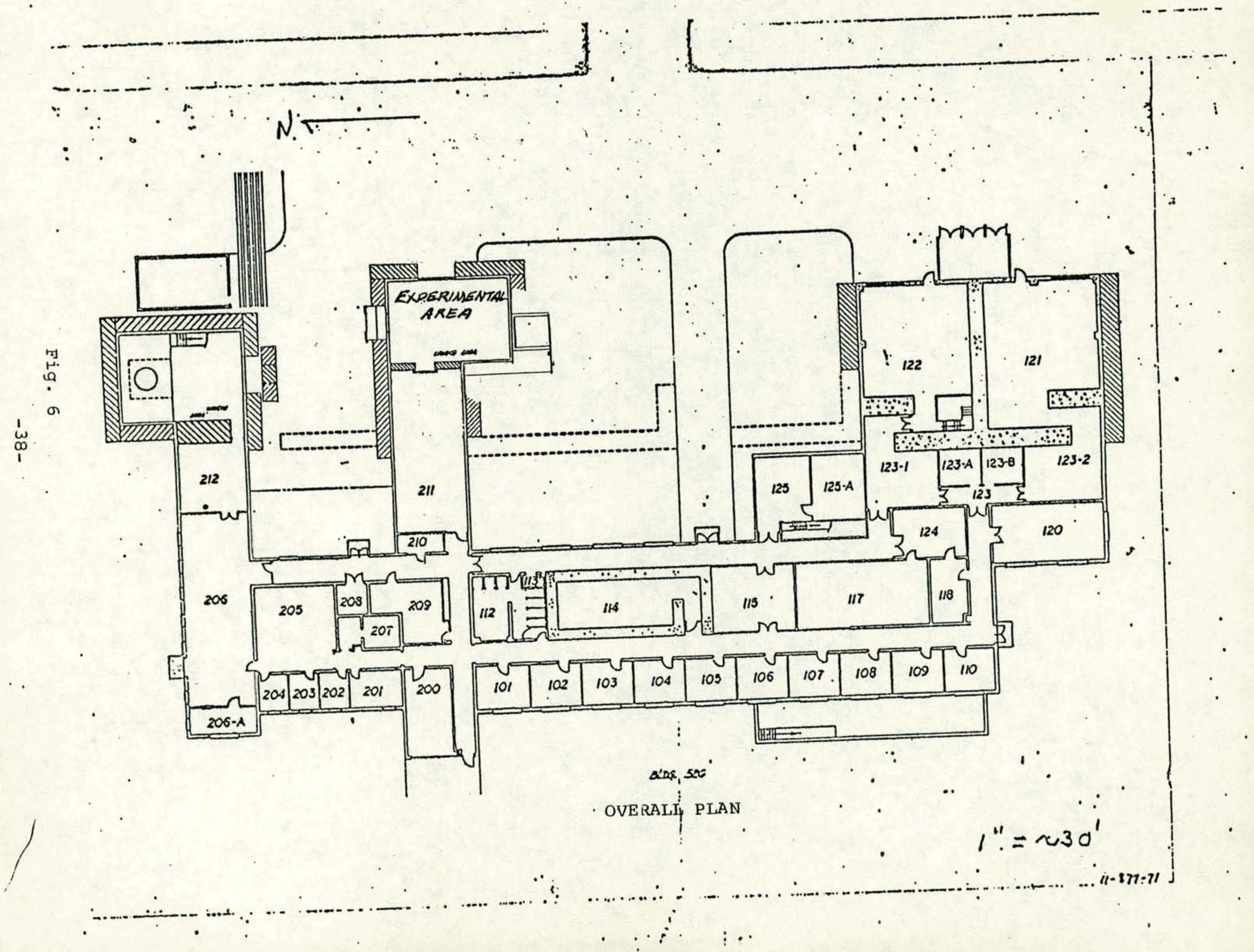


BY.

DATE

CHKD. BY

DATE.

BRIOKHAVEN NATIONAL LABQRATURY SUBJECT.COAL HYORPRYBOLYSIS. EXPERIMEN-DE-DIL OE DET OTEHEAER
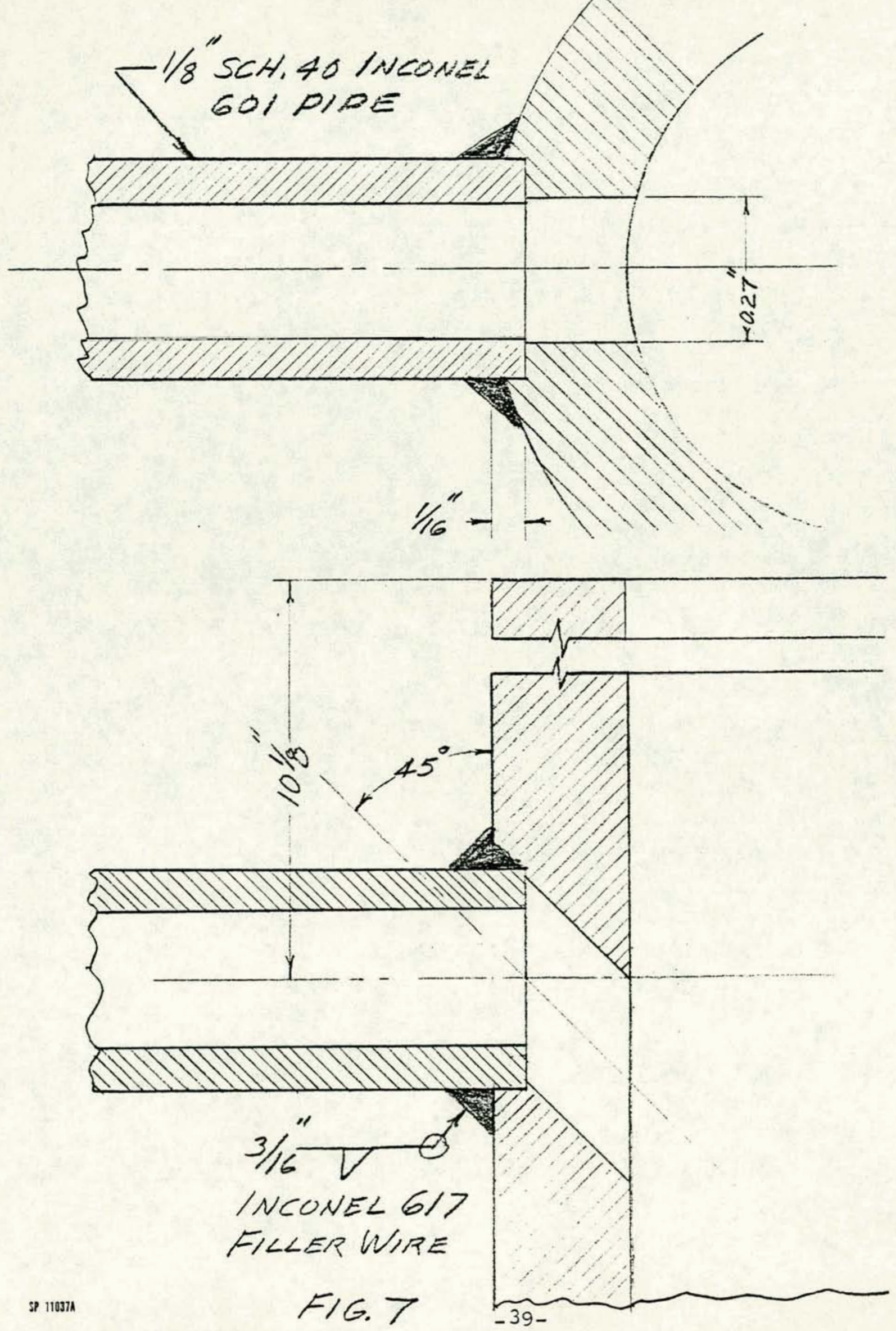
COAL HYYRODYYOLYSIS EXPEAMIEUT

- DETAIL OF SAMPLE THPS SCALE I"I/L"
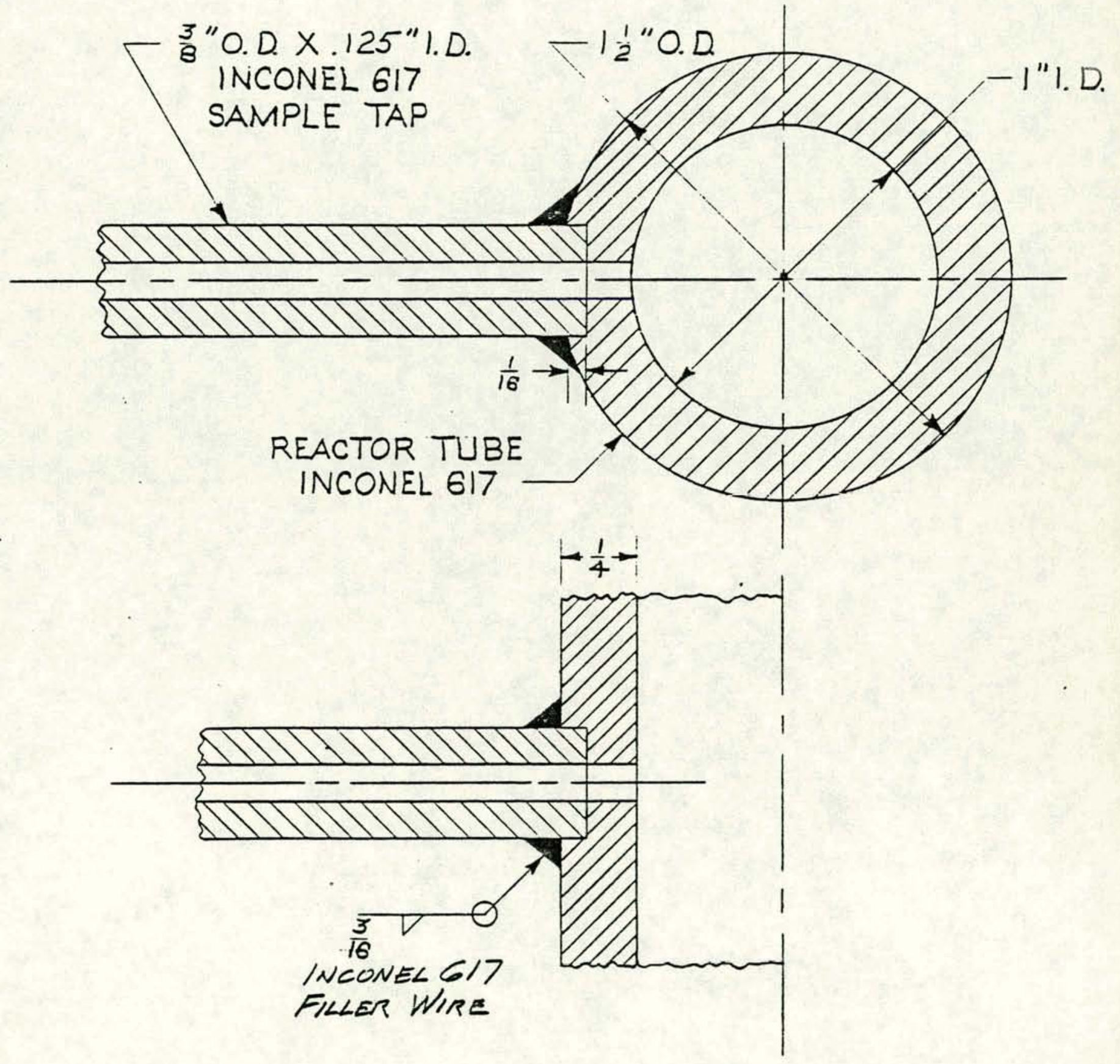

Fig. 8 


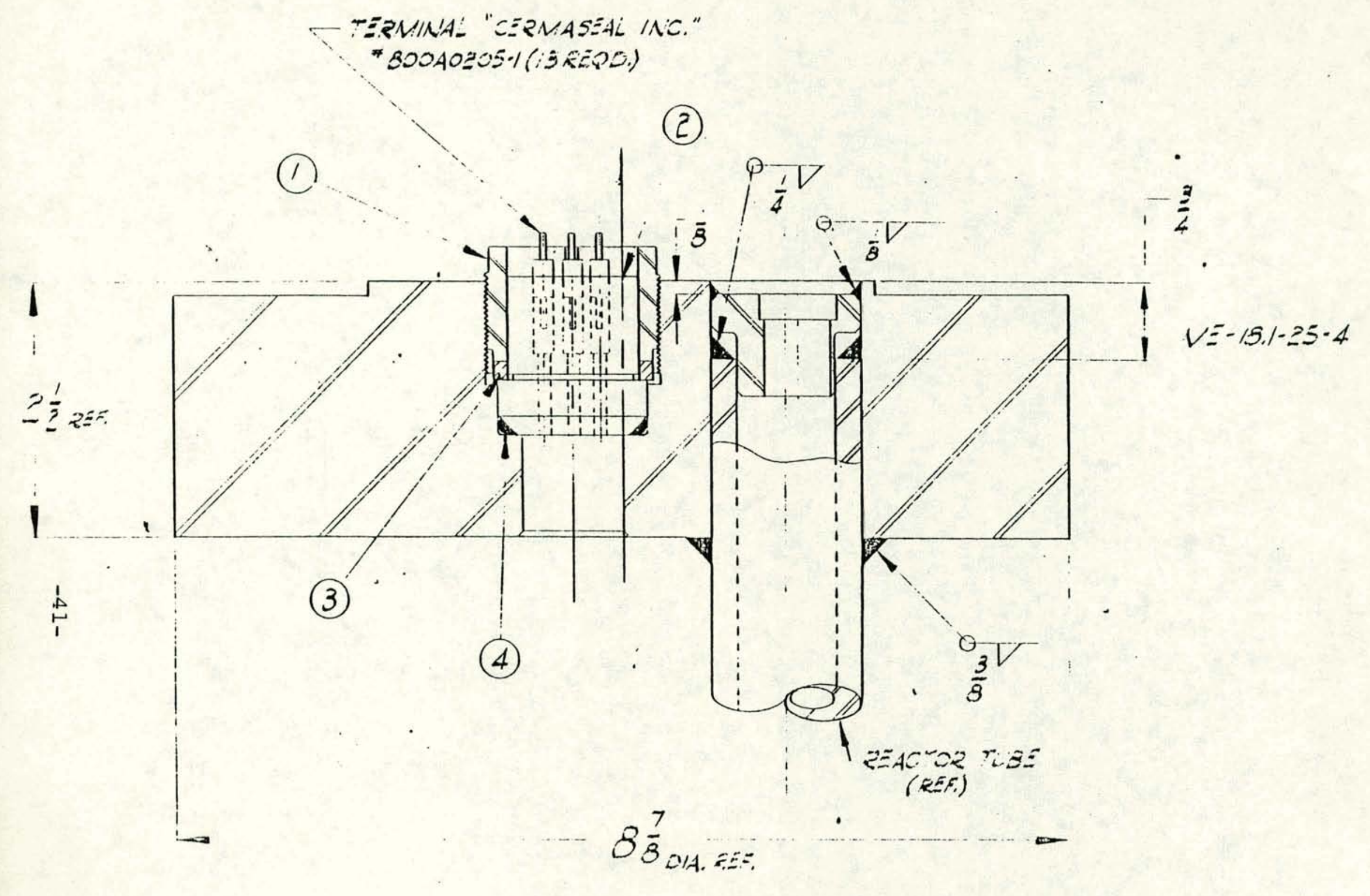

HOPPER VESSEL FLANGE

FIE. Y 
DEPT. OR PRAJECT.

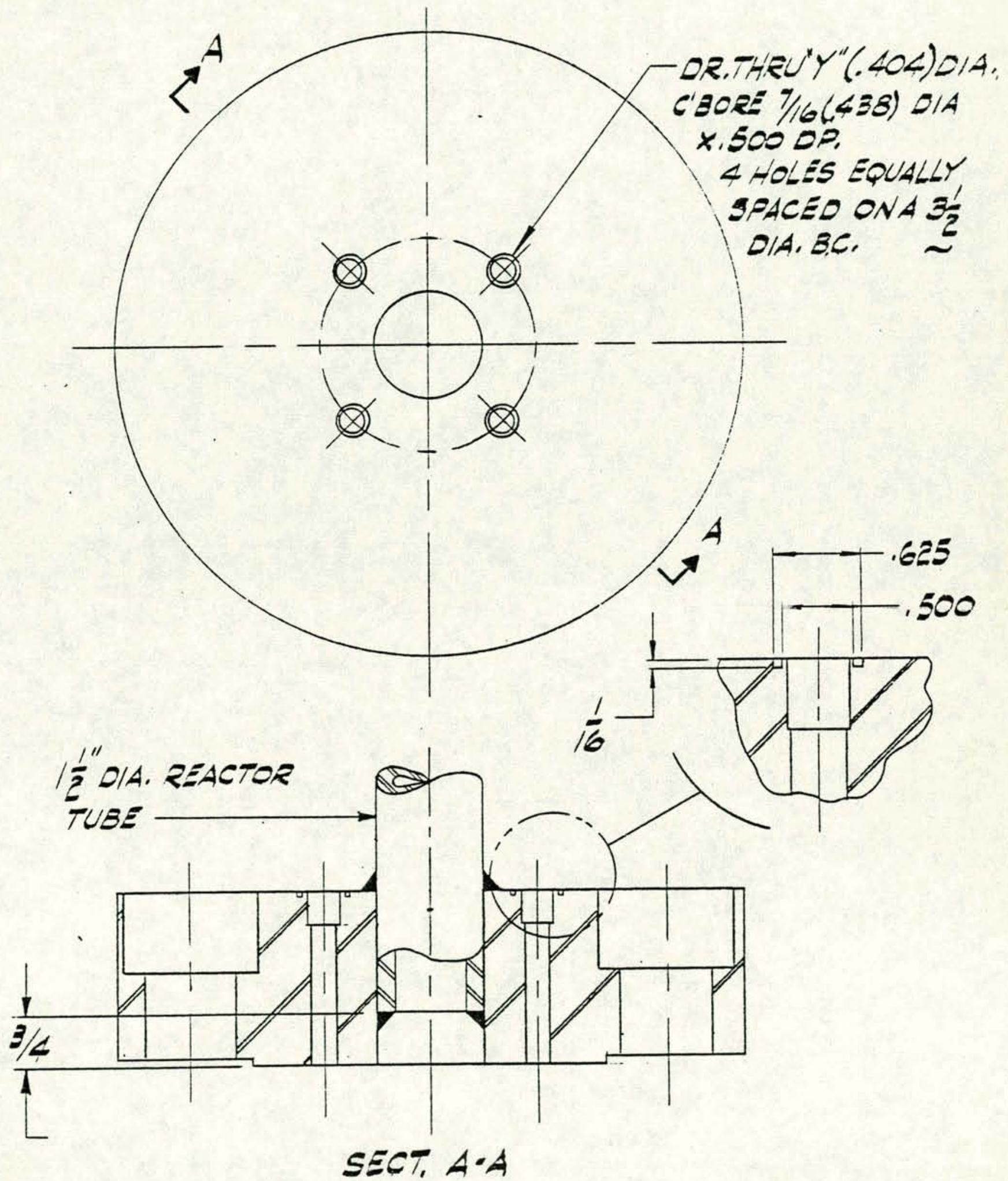

Fig. 10 
1976 SAFETY TEST OF PHP EQUIPMENT WEEK OF

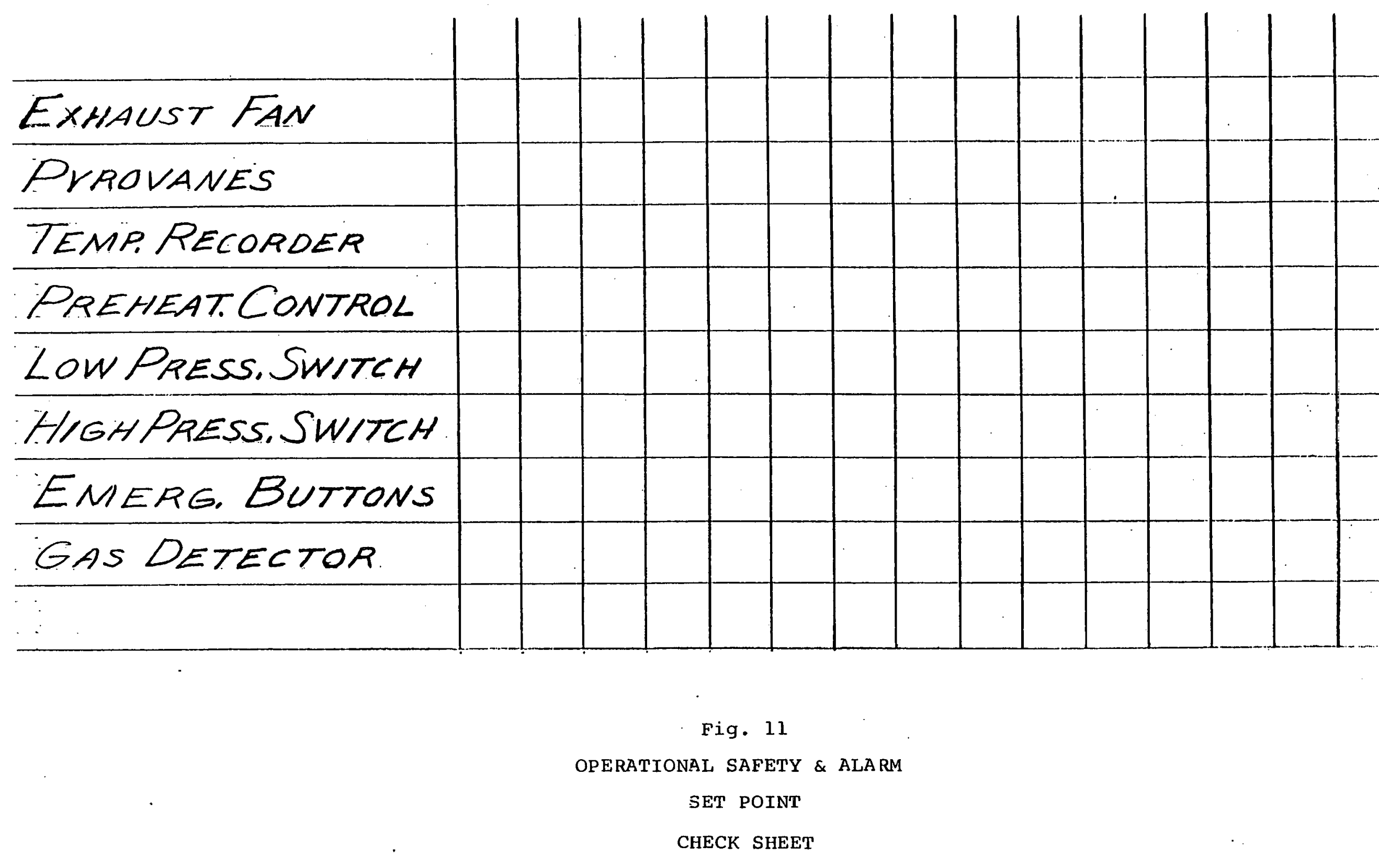




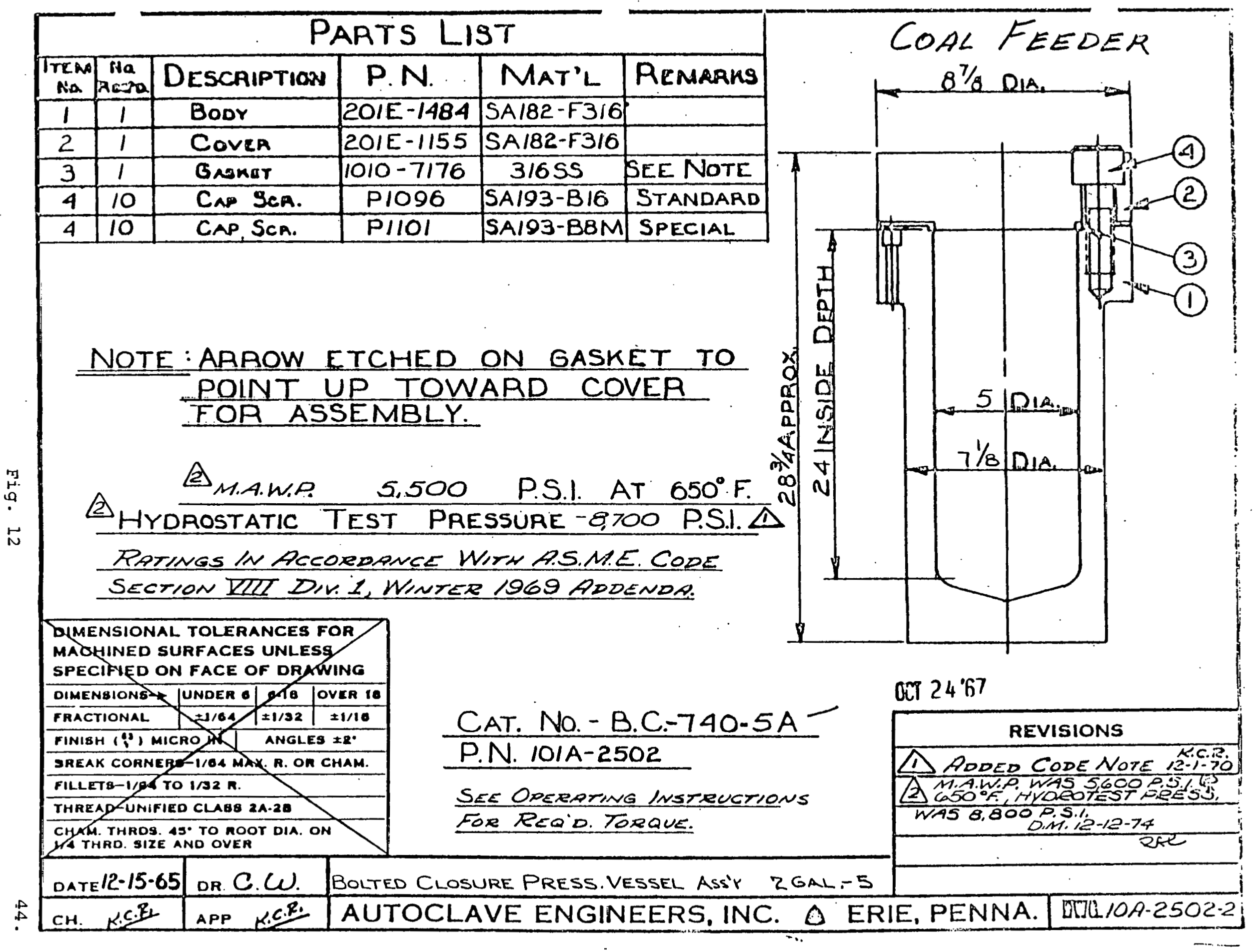




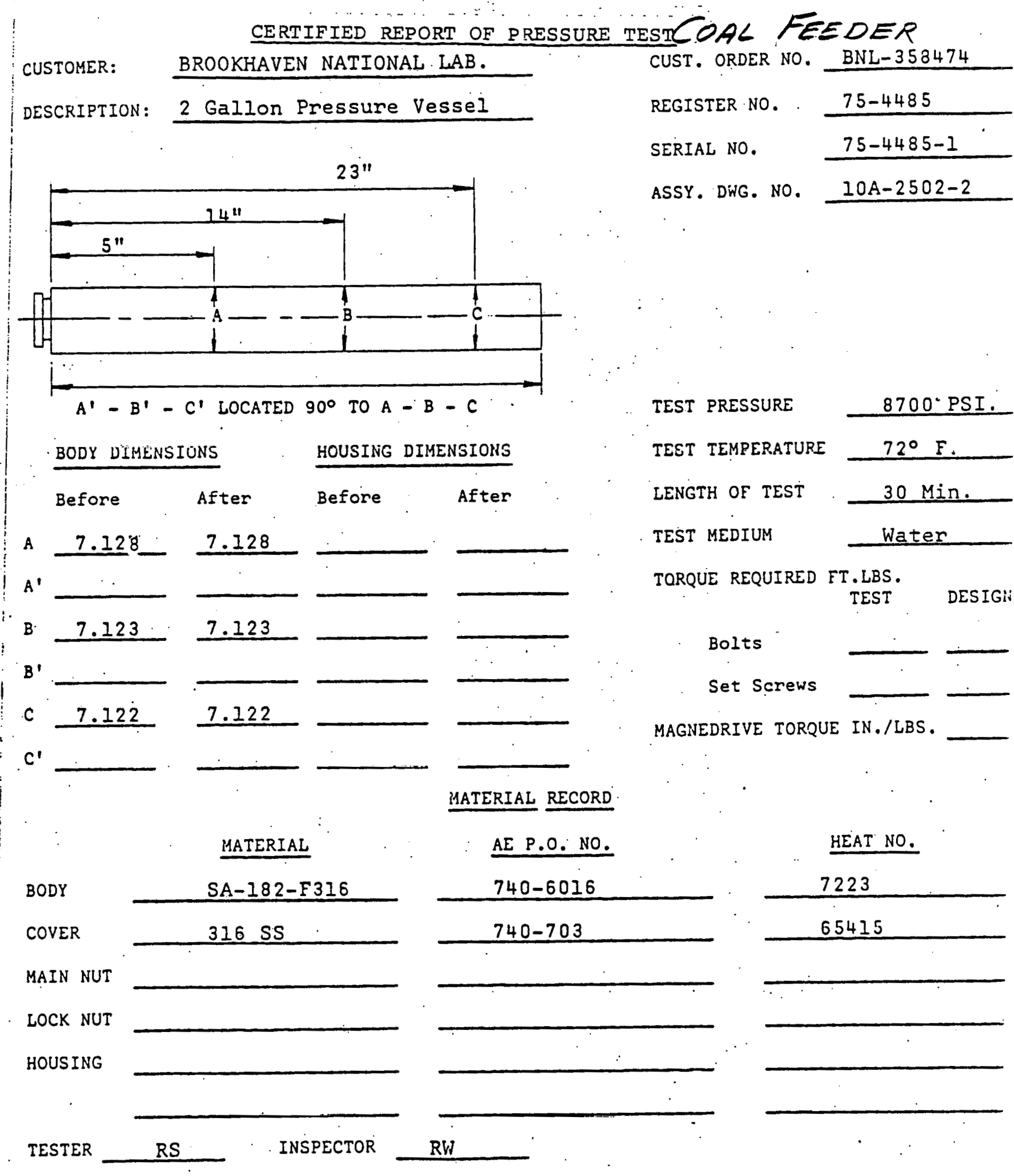

I hereby certify that the unit herein described was hydrostatically tested on $8 / 21 / 7$ at the pressure and for the length of time shown in the above test data. AUTOCLAVE ENGINEERS, INC. 


\begin{tabular}{|c|c|c|c|c|c|}
\hline & & & ARTS LI & ST & \\
\hline $\begin{array}{l}\text { ITEM } \\
\text { Mo. }\end{array}$ & \begin{tabular}{|c|}
$\mathrm{Na}$ \\
$\mathrm{Ra} 2 \mathrm{a}$
\end{tabular} & DESCAIPTION & P.N. & MAT'L & Pemarks \\
\hline 1 & 1 & Boor & $201 E-1472$ & $5 A / 82-F 3 / 6$ & \\
\hline 2 & 1 & Cover & $201 E-1155$ & SAIOL-F $3 / 6$ & \\
\hline 3 & 1 & GASMET & $1010-7176$ & 31655 & SEE Notw \\
\hline 4 & 10 & Cap Sea. & P1096 & SA193-BI6 & STANDARD \\
\hline 4 & 10 & CAP SCA. & $P 1101$ & SA/93-BOM & SPECIAL \\
\hline
\end{tabular}

NOTE: ArRoW ETched ON. Gasket TO PoInt UP. TOWARd Cover FOR ASSEMELT

Max. Allow.

Working PaEssure - 5500 P.S.I. AT $650^{\circ} \mathrm{F}$ HYDROSTATIC TEST PRESSURE - 8700 P.S.1.1120 Ratings in Accordance WITH ASME CODE SECTION JUTJ DIV I, WINTER 1969 ADDENOA

DIMENSIONAL TOLERANCES FOR MAOHINED SURFACES UNLESS SPECIFIED ON FACE OF DRAWING \begin{tabular}{l} 
DIMENSIONSS UNDER O \\
\hline FTO
\end{tabular} \begin{tabular}{ll|l}
\hline FRACTIONAL & $\pm 1 / 04 / 1 / 32$ & $\pm 1 / 10$
\end{tabular} FINISH I'P, MICRO AR ANGLES $\pm 2^{\circ}$ SREAK CORNEGS-1/04 MAX R. ON CHAM. FILLETS-1/0R TO I/A2 R. THAEAP UNIFIED CLAOS 2A.20 THA TM THROg $45^{\circ}$ TO nOOT DIA. ON SHA THRO. SIXE AND OVER date 12-15-85 Da. C.W. Bolted Closure press. Vessel Ass'y. I Gal. 5 CAT. NO. B.G.370-5A P.N. 101 A- 2500 See Operating instryctons For RECD TORQVE (\$1995) D

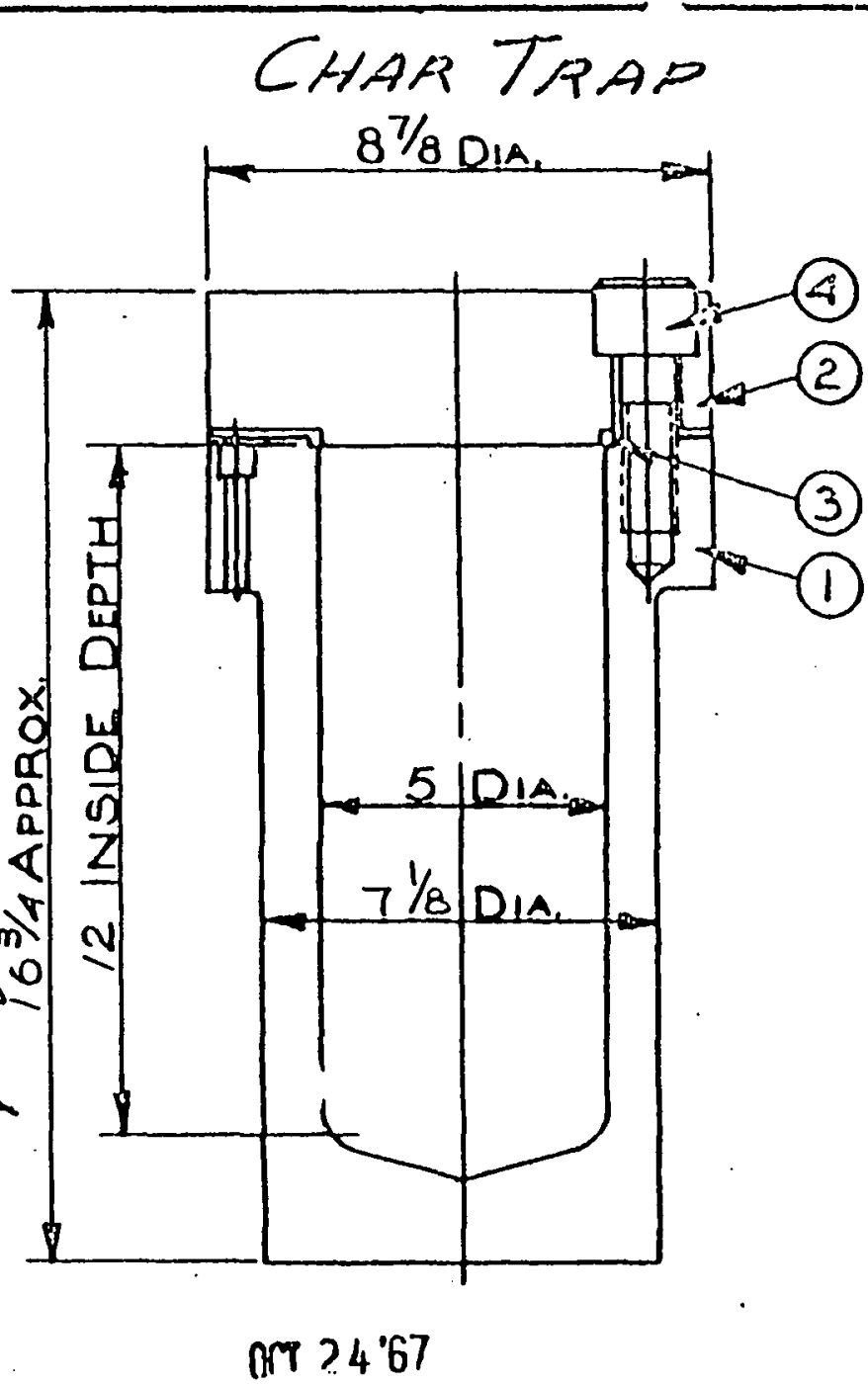

aT $24^{\circ} 67$

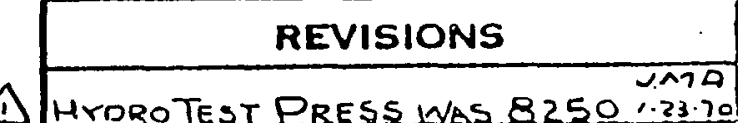
ADDED CODE NOTE Sak- SC 


\section{STOMER: BROOKHAVEN NATIONAL LAB. \\ ESCRIPTION: I Gallon BC Pressure Vessel}

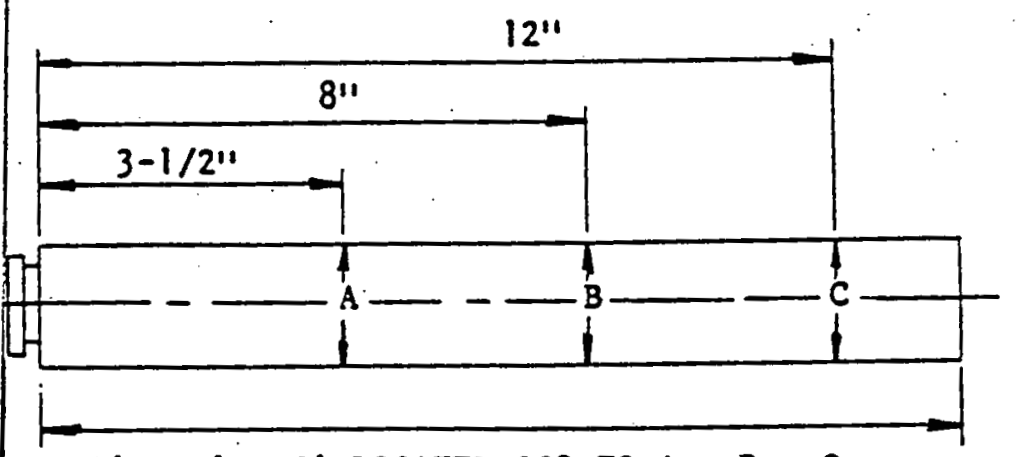

$A^{\prime}-B^{\prime}-C^{\prime}$ LOCATED $90^{\circ}$ TO $A-B-C$

BODY DIMENSIONS HOUSING DIMENSIONS

Before After Before After

$7.124 \quad 7.127$
,
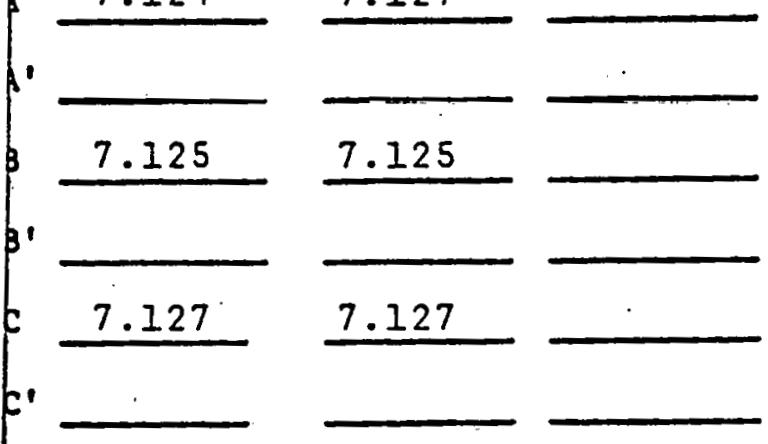

MATERIAL

\begin{tabular}{ll} 
BODY & 316 \\
COVER & 316 \\
\hline
\end{tabular}

MAIN NUT

LOCK NUT

HOUS ING

TESTER

INSPECTOR
CUST. ORDER NO. BNL 366760

REGISTER NO.

$75-6813$

SERIAL NO.

$75-6813-1$

ASSY. DWG. NO. 10A-2500-2

TEST PRESSURE
TEST TEMPERATURE $\frac{8700 \mathrm{PSI} .}{72^{\circ} \mathrm{F} .}$
LENGTH OF TEST
TEST MEDIUM
TORQUE REQUIRED FT.LBS.
\[ \text { TEST DESIGN } \]
SET SCrEWS
MAGNEDRIVE TORQUE IN./LBS.

MATERIAL RECORD

AE P.O. NO.

HEAT NO.

$740-705$

$740-703$

73510

65415

I hereby certify that the unit herein described was hydrostatically tested on $10 / 20 / 25$ at the pressure and for the length of time shown in the above test data. AUTOCLAVE ENGINEERS, INC. 


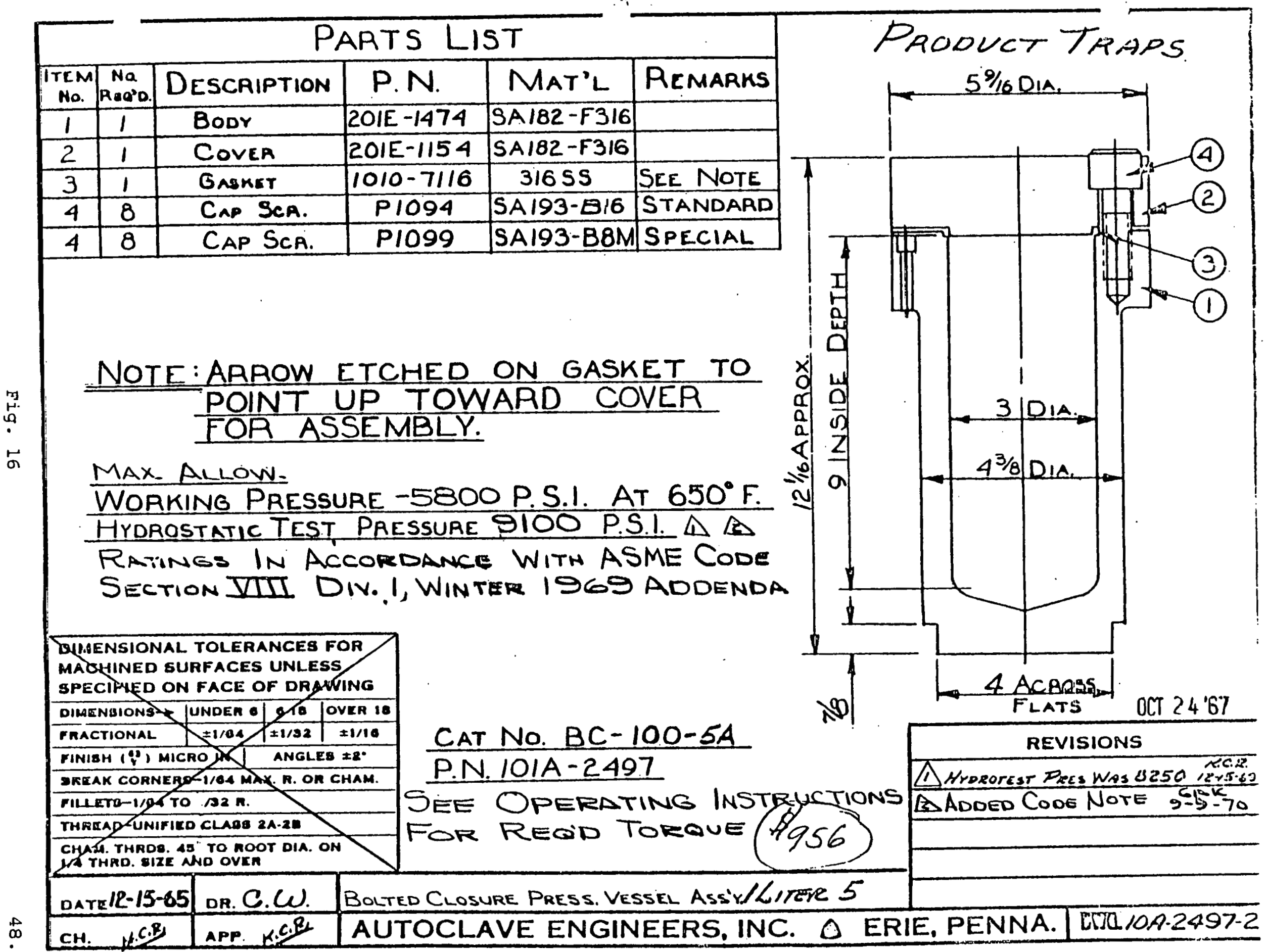




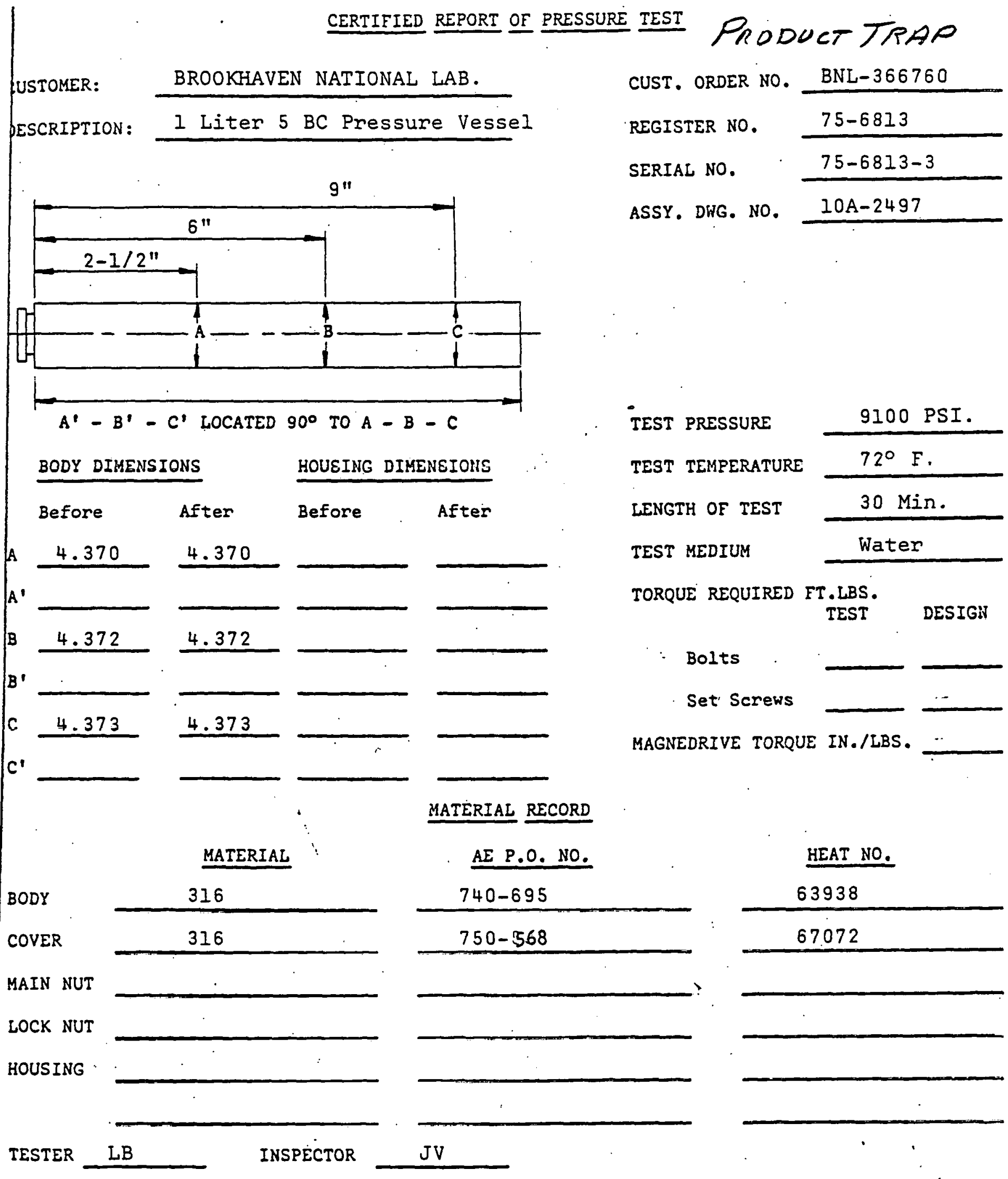

I hereby certify that the unit herein described was hydrostatically tested on $10 / 20 / 75$ at the pressure and for the length of time shown in the above test data. AUTOCLAVE ENGINEERS, INC. 
CUSTOMER: BROOKHAVEN NATIONAL LAB.

DESCRIPTION: I Liter 5 BC Pressure Vessel

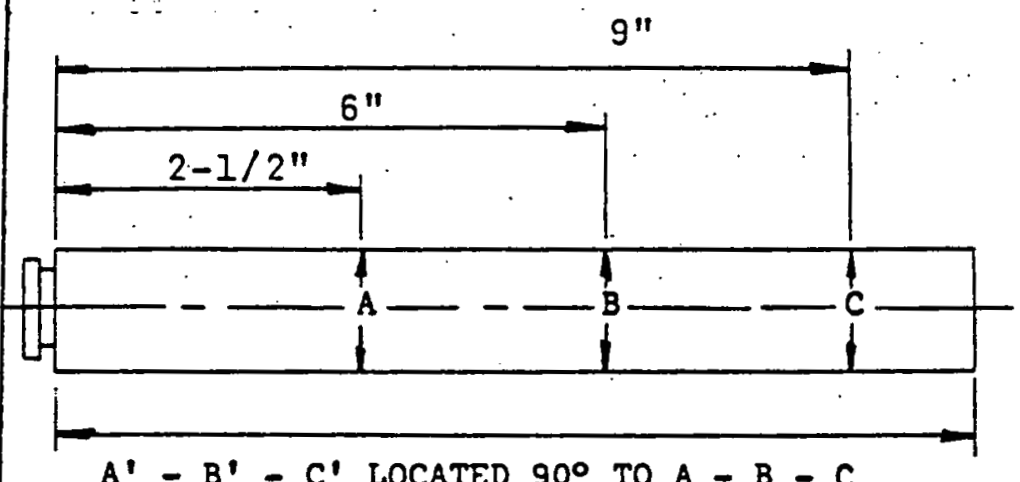

$A^{\prime}$ - $B^{\prime}$ - $C^{\prime}$ LOCATED $90^{\circ}$ TO A - B - C

BODY DIMENSIONS HOUSING DIMENSIONS

Before After Before After

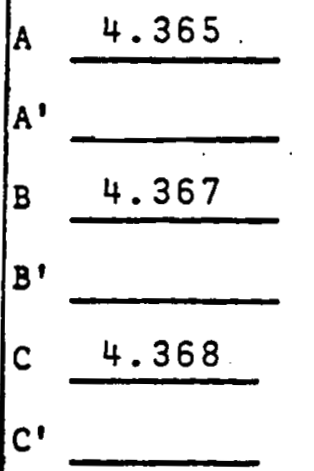

$\frac{4.366}{-}$

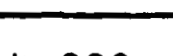

4.368
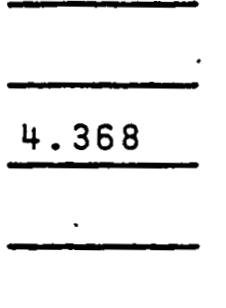

MATERIAL

\begin{tabular}{ll} 
BODY & 316 \\
COVER & 316 \\
\hline
\end{tabular}

MAIN NUT

LOCK NUT

HOUS ING

TESTER

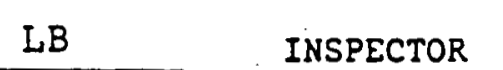

JV

MATERIAL RECORD

AE P.O. NO.

TEST PRESSURE

9100 PSI.

TEST TEMPERATURE $72^{\circ} \mathrm{F}$.

LENGTH OF TEST

TEST MEDIUM

$30 \mathrm{MIn}$.

TORQUE REQUIRED FT.LBS.

TEST

DESIG:

Bolts

Set sarews

MAGNEDRIVE TORQUE IN./LBS.

I hereby certify that the unit herein described was hydrostatically tested on $10 / 20 / 7$ ! at the pressure and for the length of time shown in the above test data. AUTOCLAVE ENGINEERS, INC. 


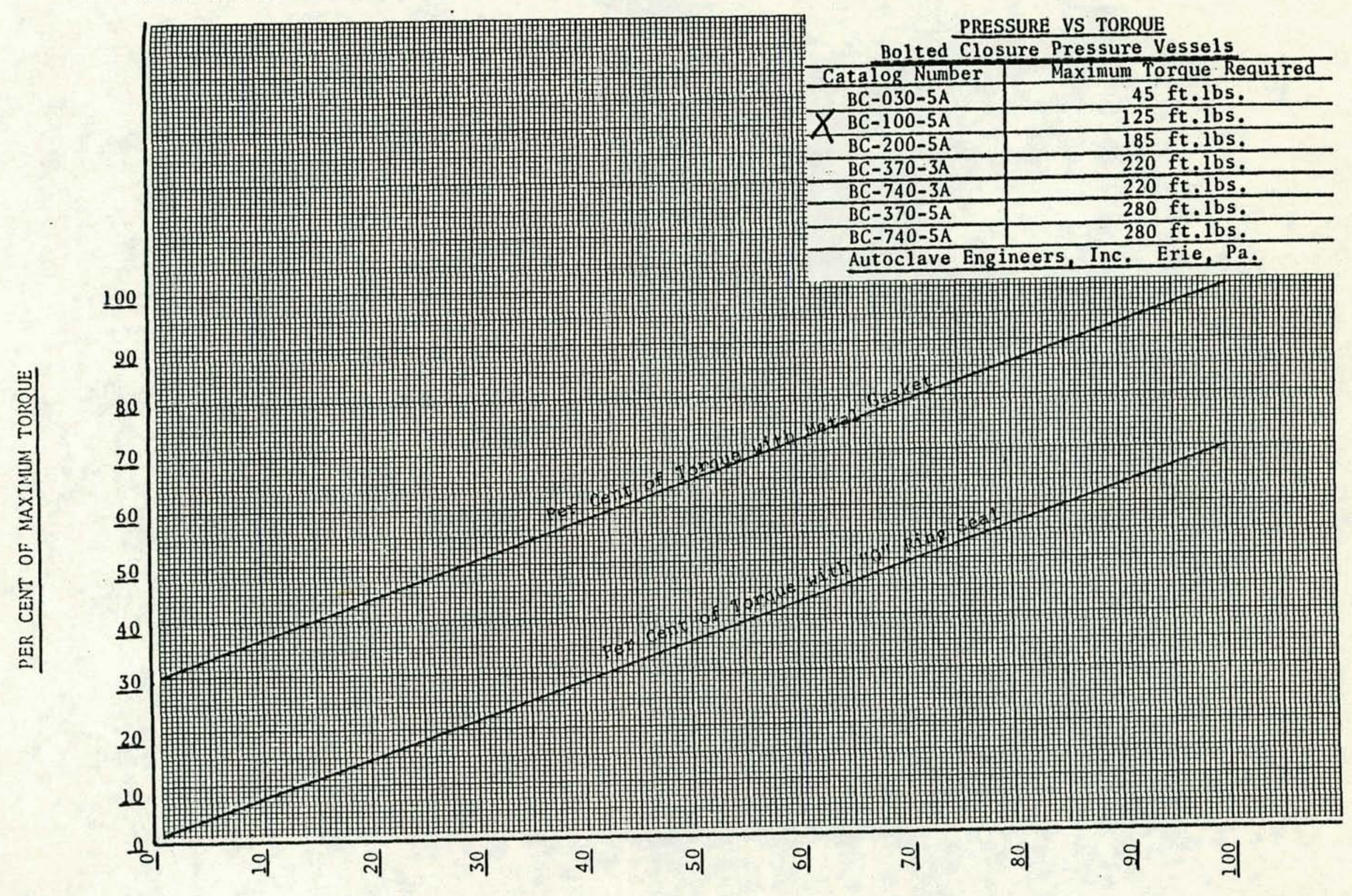

PER CENT OF MAXIMUM OPERATING PILSSSURE 


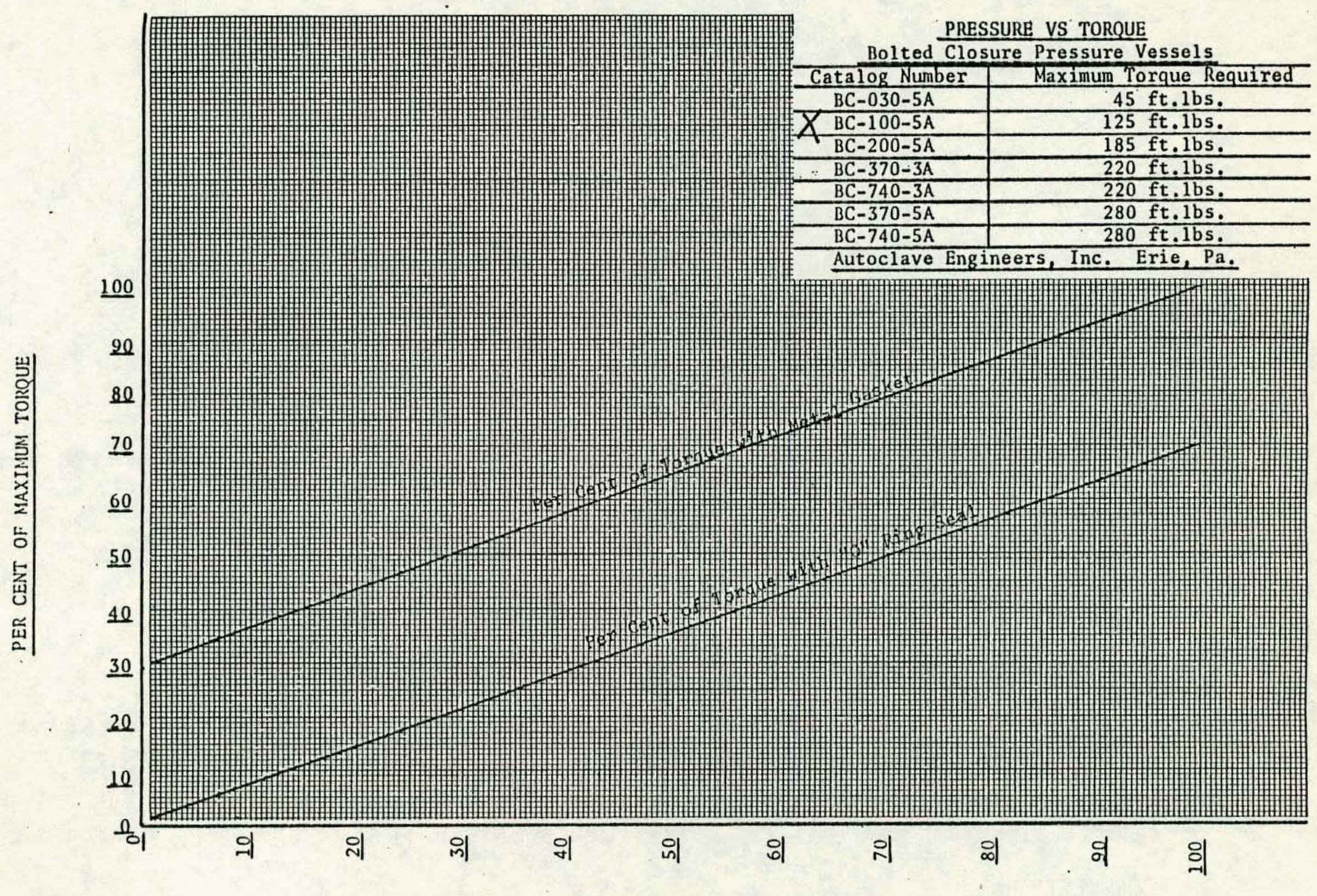

PER CENT OF MAXIMUM OPERATING PRUSSURE

Fig. 19 


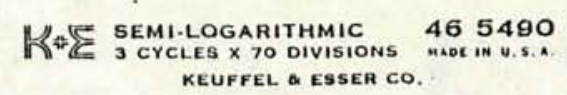

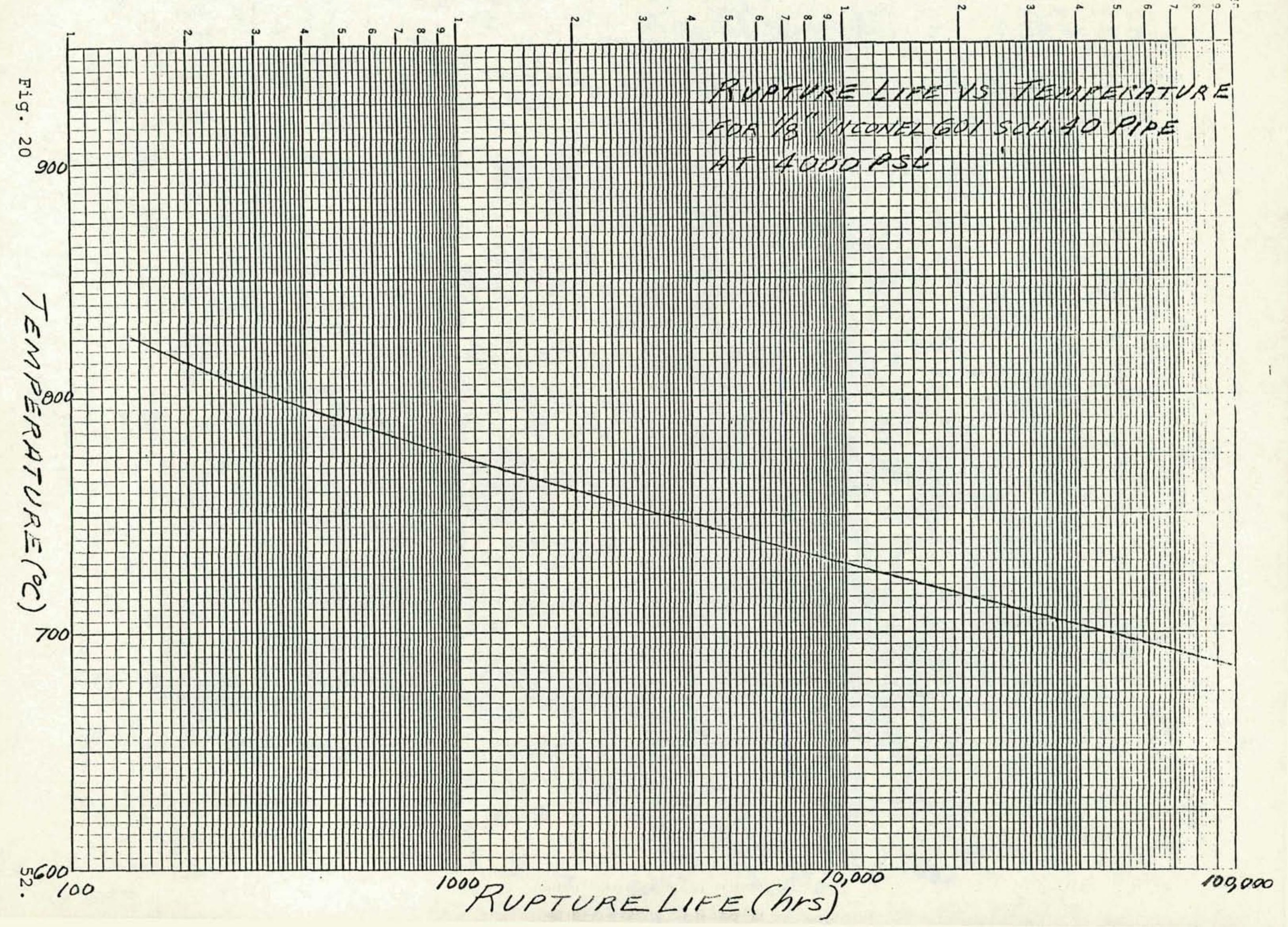

